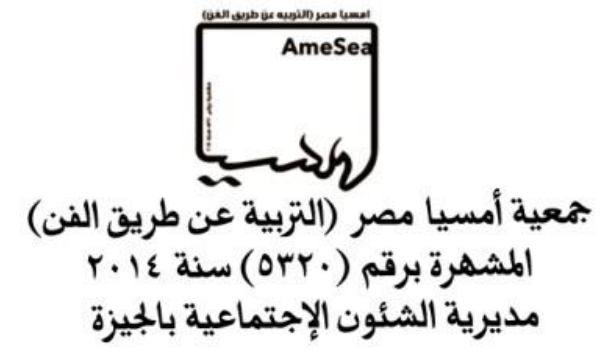

العلاقة التبادلية بين تصميم طباعة المنسوجات وتصميم الازياء

\author{
إعداد \\ أ.د. هدى صدقي \\ د.منى محمد سيل نصر \\ د. شبماء عادل دياب
}




\section{: Introduction: مقدمة}

الخط من اهم العناصر التى يستخدما المصمم فى عمله و ابسطها فالتصميمات تبدأ بالتخطيط و التحديد لعناصر التصميم

المختلفة ، فالخط يعطى العمل الفنى الوضوح و الايقاع الديناميكى ـ كما انه ايضا يعتبر من اكثر العناصر تعقيدا ،و إذا

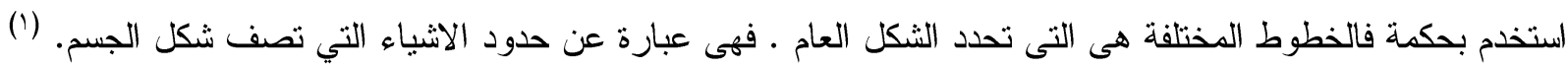
ولا يخلو أي عمل فني من عنصر الخط لما له من إمكانات غير محدودة وأنواع مختلفة ، فقد يكون مستقيماً أو منحنياً أو

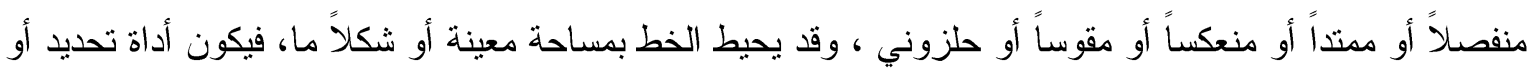

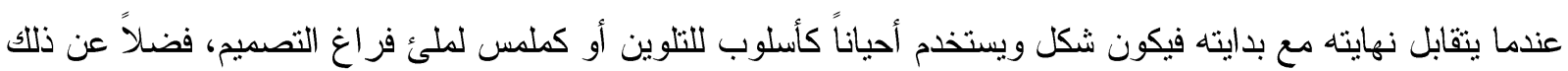
يمكن للخط أن يستثير شعوراً بالتجسيم أو ينتج عنه خداع بصري ، يصعب أدرالك الخط بمفرده فى الفنون التشكيلية لأنه لا معنى له بمعزل عن تحركاته وأوضاعه و أبعاده ، وتكرار نظم توزيعه ، فللخط دور كبير فى تصميمات أقمشة ملابس

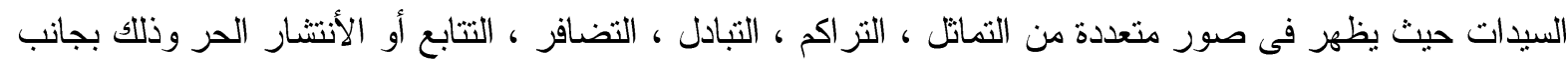
التتويع فى التكبير و التصغير إلا أن الخطوط البنائية للزى نفسه قد تحدث تغيير ا كبير ا فى شكل التصميم الطباعى ليظهر بـا بشكل أبتكاري جديد وذلك لأن التصميم الطباعى المعتمد على الخط له إتجاه ومع ما يتعرض له هذا التصميم الطباعى أثناء عملية التفصيل منأثرا بالخطوط البنائية للزى نفسه قد تغيير إتجاهه أو سمكه من خلال القصات و الكسرات إلى أخره وتغيير حركته أو نوعه من خلال الدرابيهات فيتحول الخط المستقيم إلى خط أكثر ليونة.

\section{مشكلة البحث: Statement of the problem}

تكمن مشكلة البحث في محاولة الإجابة على التسـوألات الآتىهة: - هل للخط ادو ار متعددة فى التصميم الطباعى للازياء المعاصرة ؟ -هل الخط مؤثر فى التصميم الطباعى ومعالج لعيوب الجسم ؟

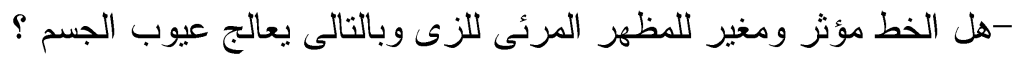
- لماذا يستمر تصميم المقلم على مر العصور كموضة كلاسيكية فى ملابس السيدات ؟ -ما الذى يجذب مصمم الازياء للاستعانه به كليا وجزيئا فى تصميماته؟ -هل يمكن الاستعاضة بالتصميم الطباعى عن خطوط الزي ومكملاته المميزة له و العكس؟ فمصم طباعة المنسوجات يهتم بمنطلبات التصميم الطباعى من (إختيار للوحدات المناسبة - مجموعات الألوان - أسلوب التكرار - مر اعاة خطوط الموضة - وضع تصميم مبتكر - كل ذلك وفقا لاسس وقو اعد التصميم ،اما مصدم الأزياء لونه فيهنم بكل ما سبق مضافا عليها ( ضرورة تتاسب الخامة و التصميم الطباعى مع تصميم الزي -و و إستخدام خطوط جريئة ومختلفة فى تصميم الزى لكى ينسجم كلا من تصميم الزي و التصميم الطباعى ونمط جسم المرتدى للزى - ........) وذللك للوصول لتصميم زى ناجح منكامل الاركان ويرضى العميل ويلبي إحتياجات السوق المستهف. فروض البحث:Hypothesis: - بقترض البحث أن : لبن - للخط ادوار متعددة فى التصميم الطباعى للازياء المعاصرة

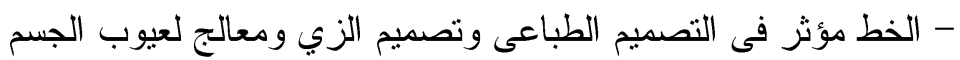

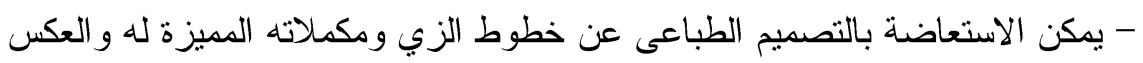


- دراسة عنصر الخط كعامل أساسي مشترك ومحرك للعلاقة بين التصميم الطباعى وتصميم الازياء

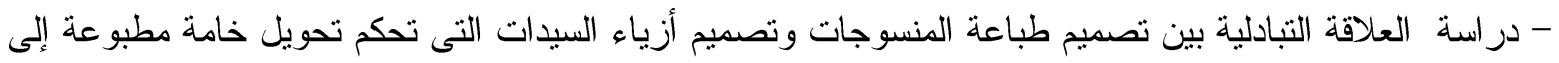
منتج ملبسي من خلال تحويل تصميم طباعة المنسوجات (ثنائي الأبعاد) إلى زى مجسم (تثلاثي الأبعاد)

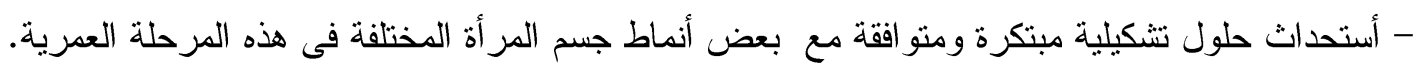
منهيجة البحث Methodology:

- المنهج الوصفي (التحليلي) لدر اسة الخط بمختلف صوره ودر اسة الارنباط بين التصميم الطباعى وتصميم الأزياء . - المنهج التجريبي بأبتكار تصميمات خطية تصلح للتصميم الطباعى لازياء السيدات و أبتكار ازياء وتصبيمات طباعية خطية للمر أة تعالج عيوب الجسم وتحسن مظهره. الإطار النظرى Theoretical framework

المحور الاول :الخط عنصر تثكبلى.

" للخط قيمه التشكيلية ودلالاته التى بها يشكل المحتوى و المظهر النهائي لأى تصميم لذا فالتعرف على مفاهيمه المختلفة

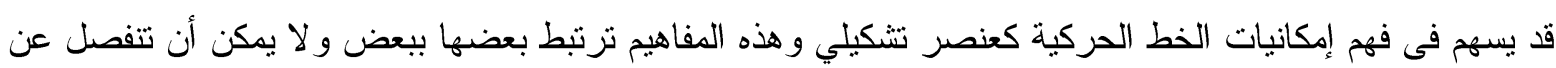

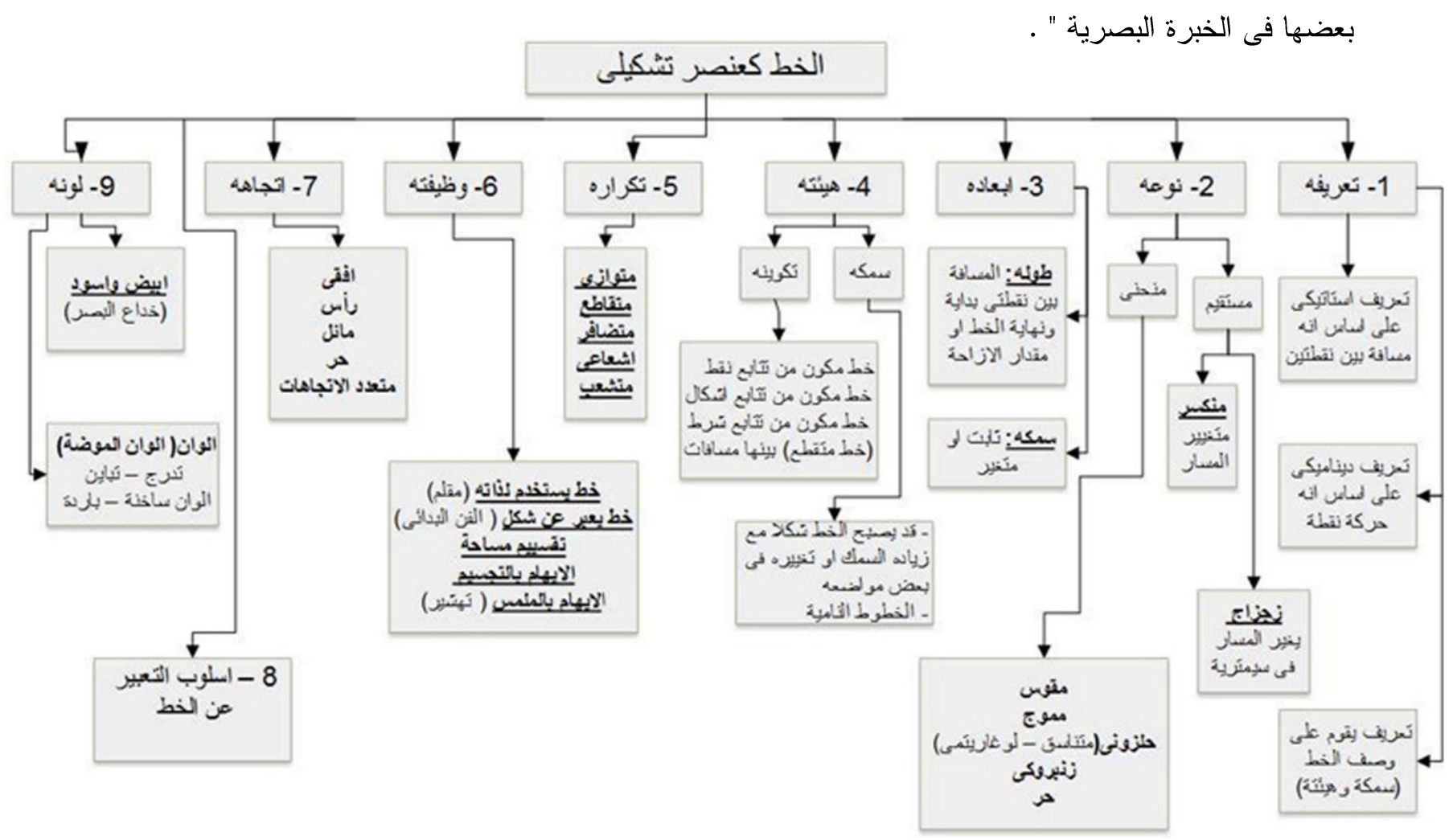

شكل (1) : الخط كنصر تشكيلى 


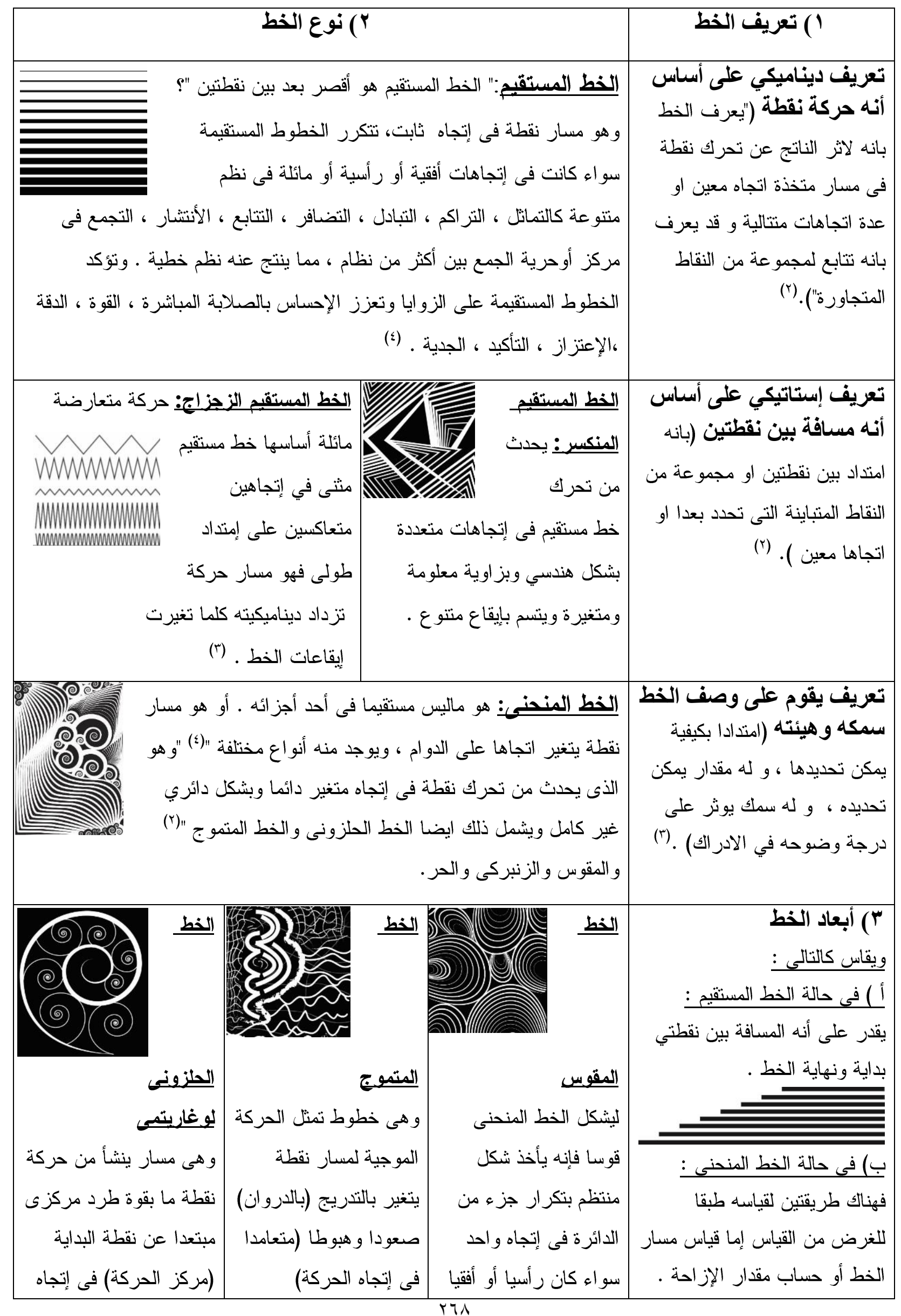




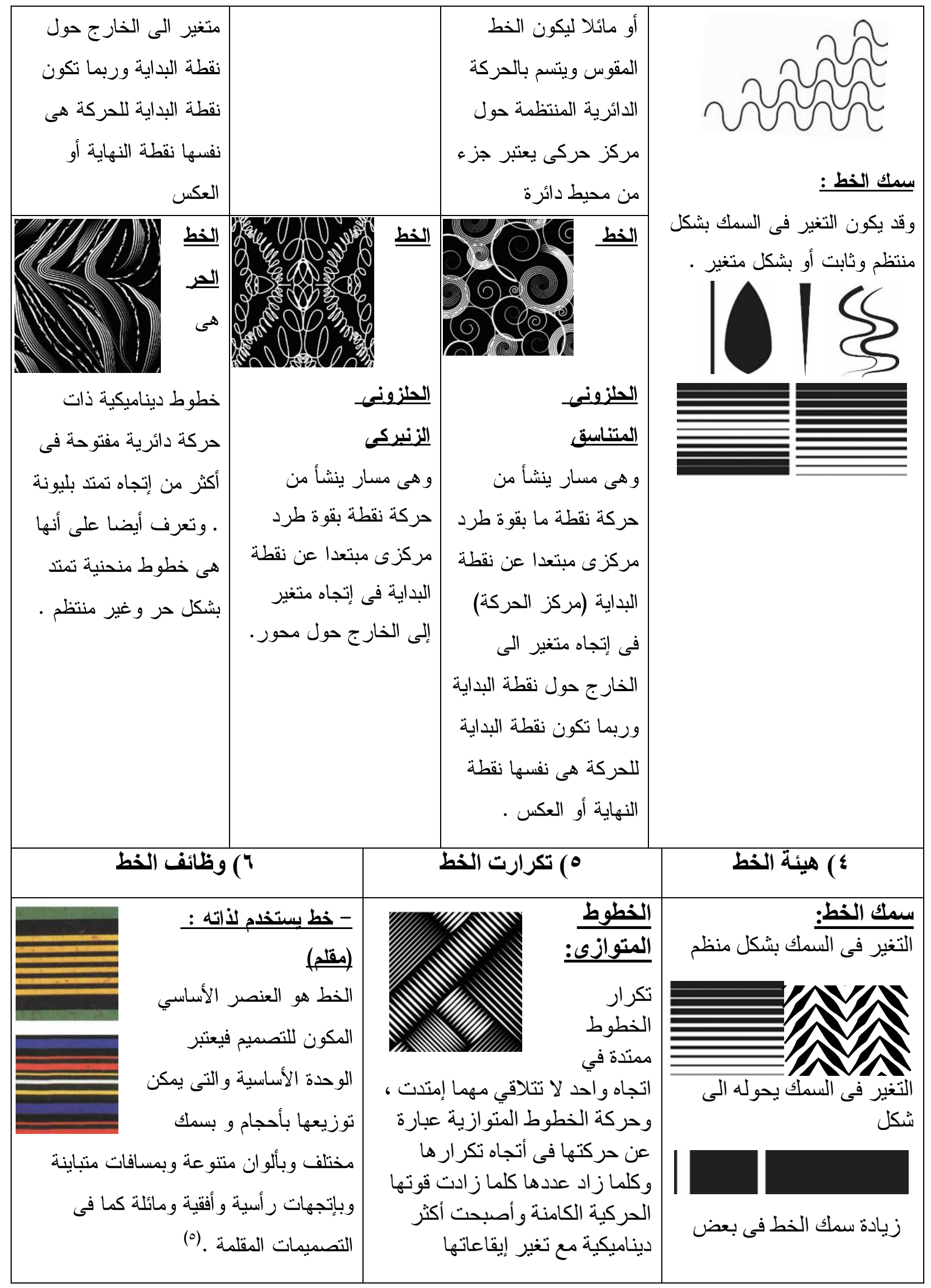




\begin{tabular}{|c|c|c|}
\hline - خط بعبر عن شكل (الرسم التخطبطي) : & الخطوط & 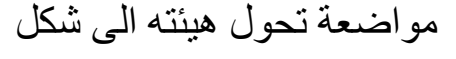 \\
\hline 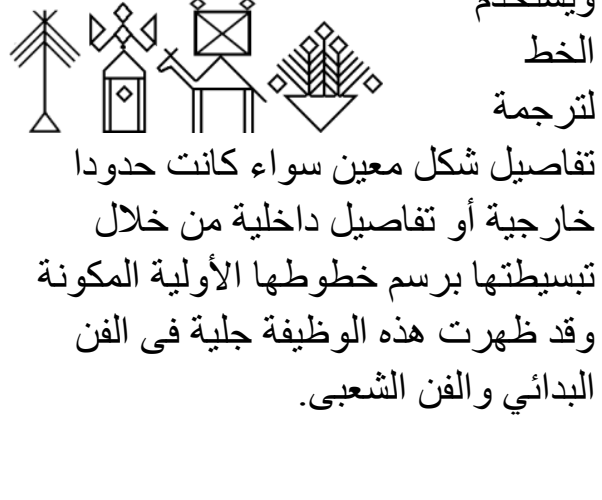 & 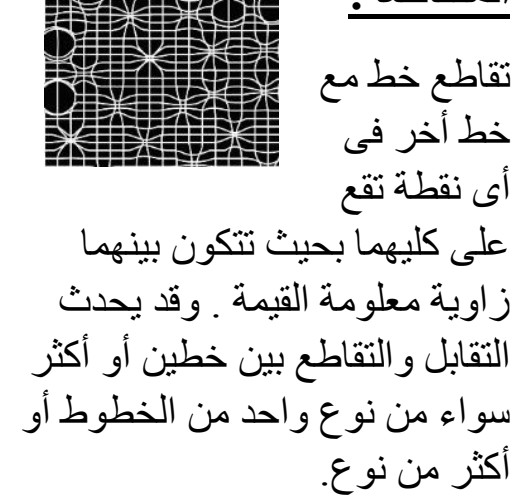 & \\
\hline 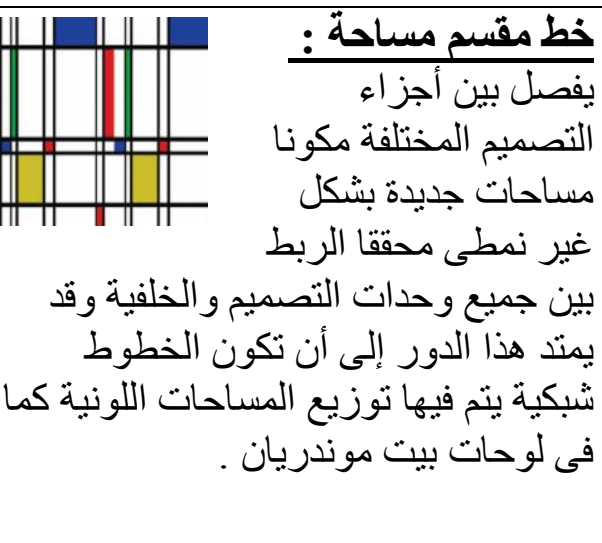 & 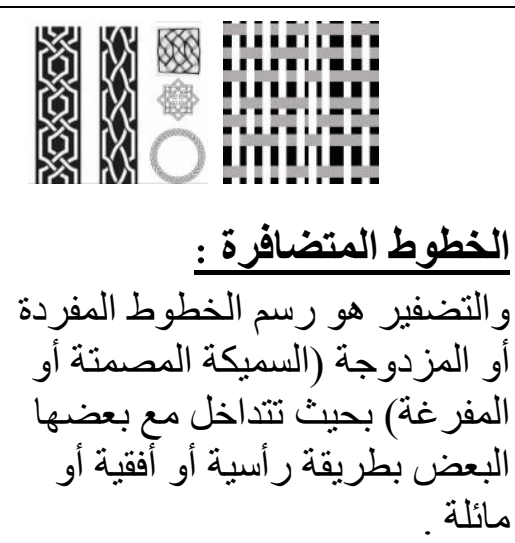 & 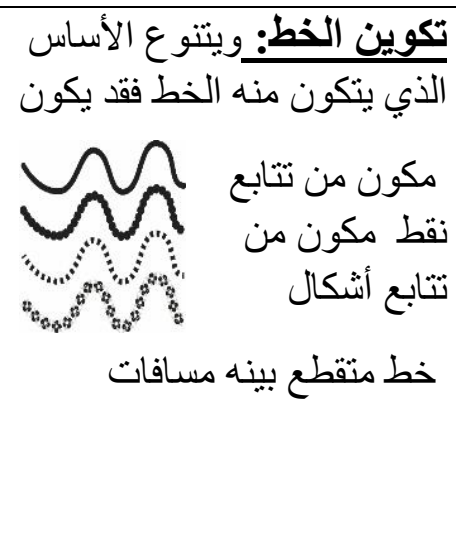 \\
\hline 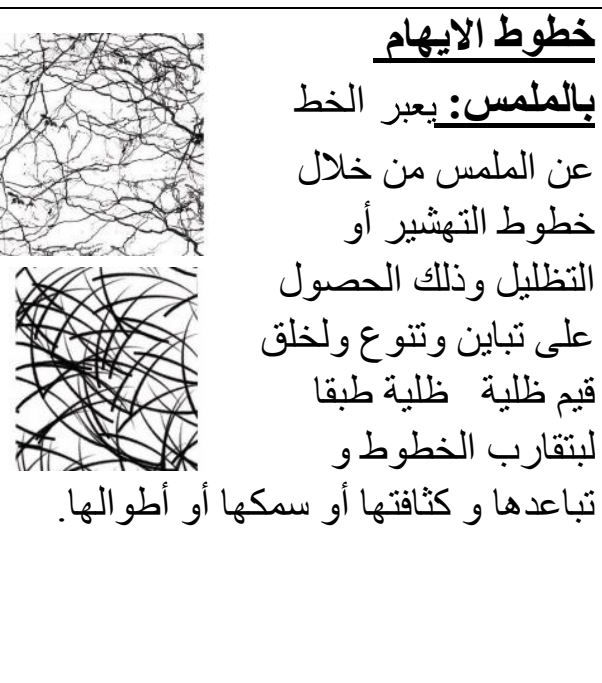 & \multicolumn{2}{|c|}{ 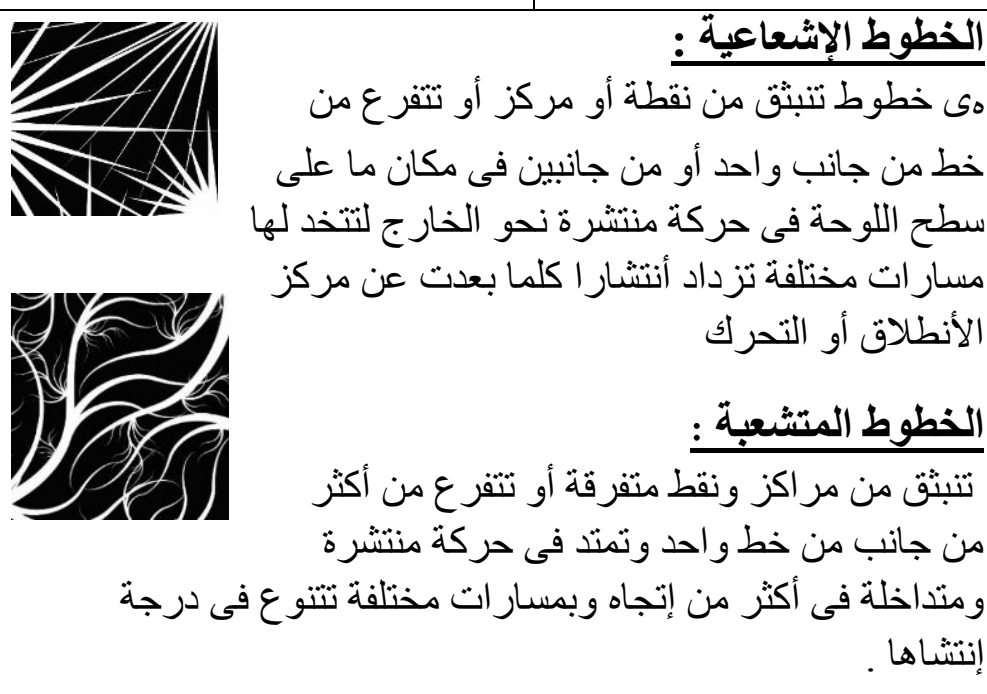 } \\
\hline 1) أسلوب التعبير عن الخط & \multicolumn{2}{|c|}{ V ( إتجاهات الخط } \\
\hline
\end{tabular}

rV. 


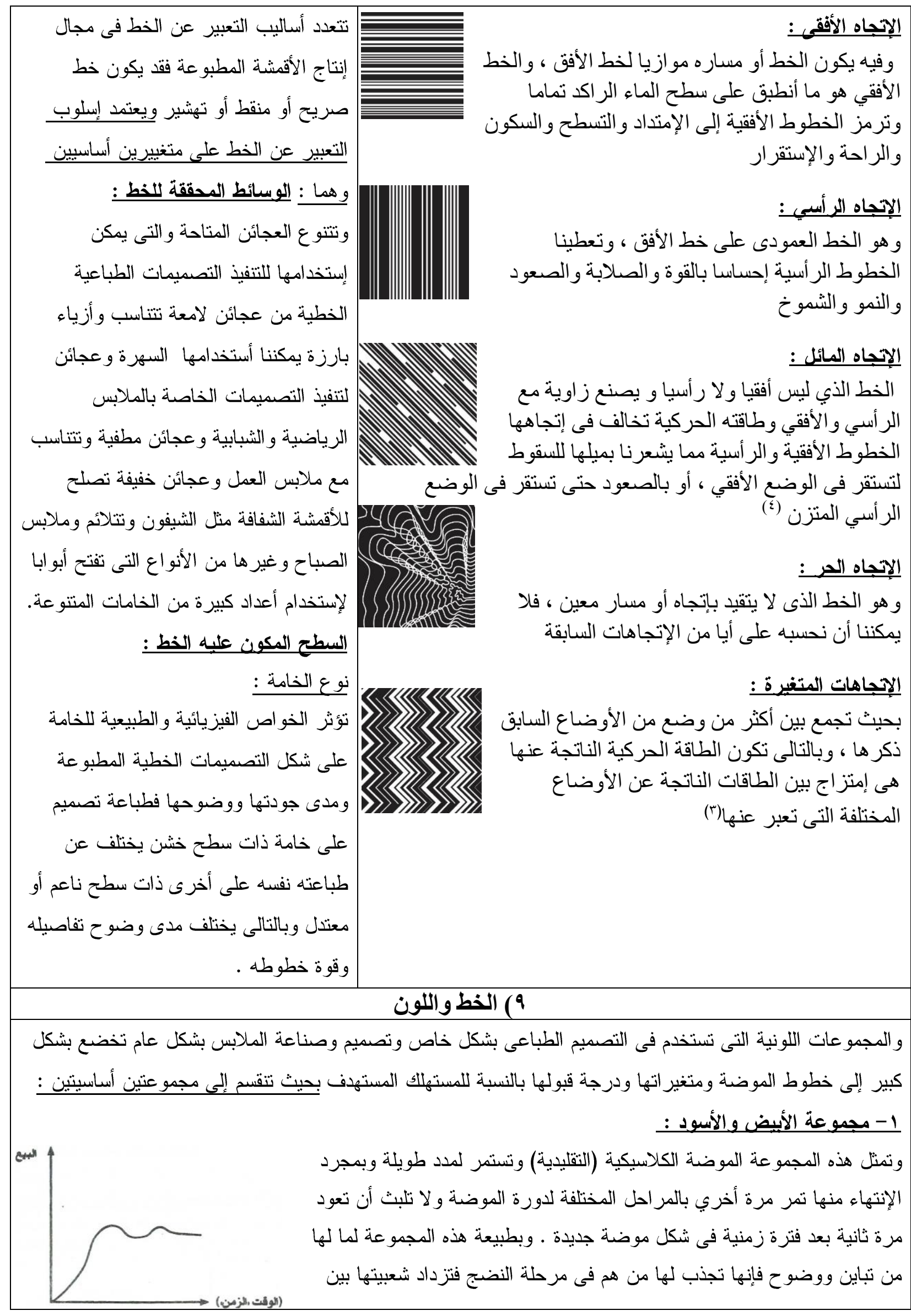

rVI 
أصحاب السن الناضح أو أصحاب السن فى حدود الفئة العمرية موضع الدراسة وذلك لملائمتها لطبيعة مرحلتهم العمرية

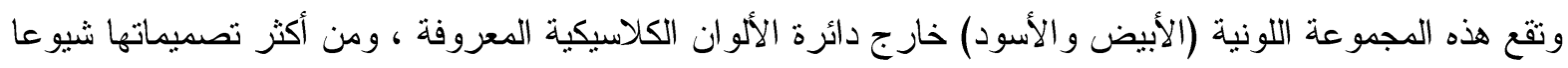
التصميمات المقلمة كذلك التصميمات التى تحقق الخداع البصري Ort و والذي سيتم تتاوله بالثرد الثرح فيما يلي . r - المجموعات اللونية

وتخضع هذه المجموعة لدورة إنتاج الموضة وقد تمتد لعدة مو اسم ويحتمل أن تعود مرة أخري حيث تعتمد على إفتر اضات يضعها مصممي الموضة ويفترضو ا تقبل المستهلك و المتلقي لها وذللك من خلال مرور ها بأربعة مر احل أساسية : أبرن : البدابة:

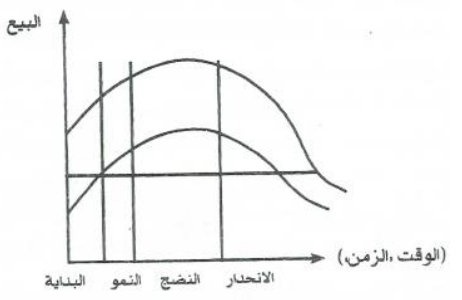
أو وقت تقديم الفكرة وبداية تقبل المستهلكين لها وفى هذه المرحلة تأخذ الموضة

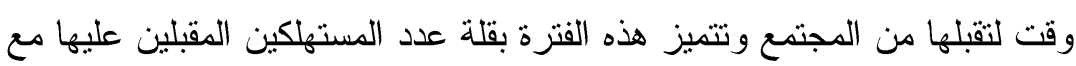

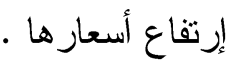
: النمو

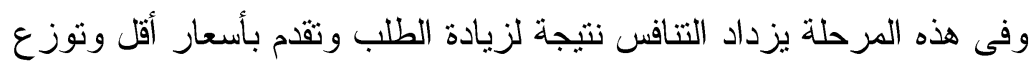

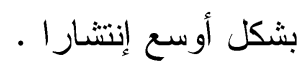
:

وفى هذه المرحلة تبقي مجموعة ألوان الموضة أطول فترة زمنية خلال دورة الموضة ويتميز بإنتاج تصميمات من هذه

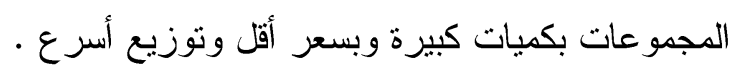
ـ - ع الإحدار

عند إنتشار مجموعات ألوان الموضة و أخذها شعبية كبيرة تبدأ بالإنحدار ويتجه المصممين إلى مجموعات لونية جديدة

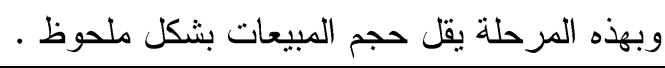

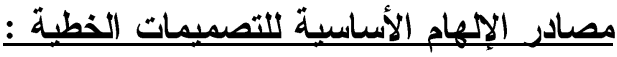

ونتاول فى هذا الجزء مصدري ألهام من أكثر مصادر الألهام التى يستخدما المصممين لإنتاج تصميمات خطية حيث تمثل تصميمات الخداع البصري والاستلهام من الطبيعة منبعا متجددا لمصممين طباعة المنسوجات ومصممي الأزياء ولكافة المهتمين بالتصميمات الخطية بشكل عام •

$$
\text { أ) الخداع البصري }
$$

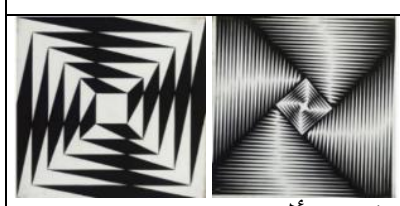

فن خداع البصر يتحقق كنتيجة لإحكام التنظيم الهندسي ، الذي يعتمد فى بعض جو انبه

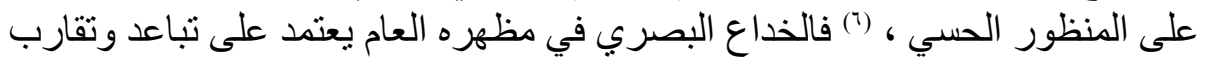

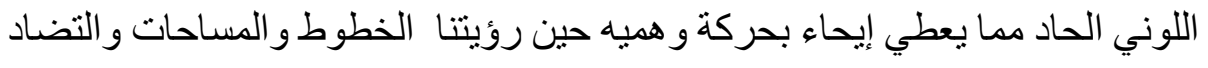
لها ، ويعود الفضل في انتشار هذا النوع من الفنون إلى الرسامين فيكتور فيساريلليي وريتشارد ألين IIIIIII

\section{الإبــام بالتحسبيح :} إستخدام الخداع البصري الخطى ليوحى بالتجسيم حيث نستغل إمكانيات الخط فى التصميم ثنائي الأبعاد للتعبير عن بعد ثالث غير موجود فى الو اقع ولكنه ناتج من خلال الحركة الإيهامية المتكونة من خلال 
الخطوط و التى نوحى بأن الثكل المرسوم ثلاثي الأبعاد بالرغم من أنه مرسوم على سطح ثنائي .

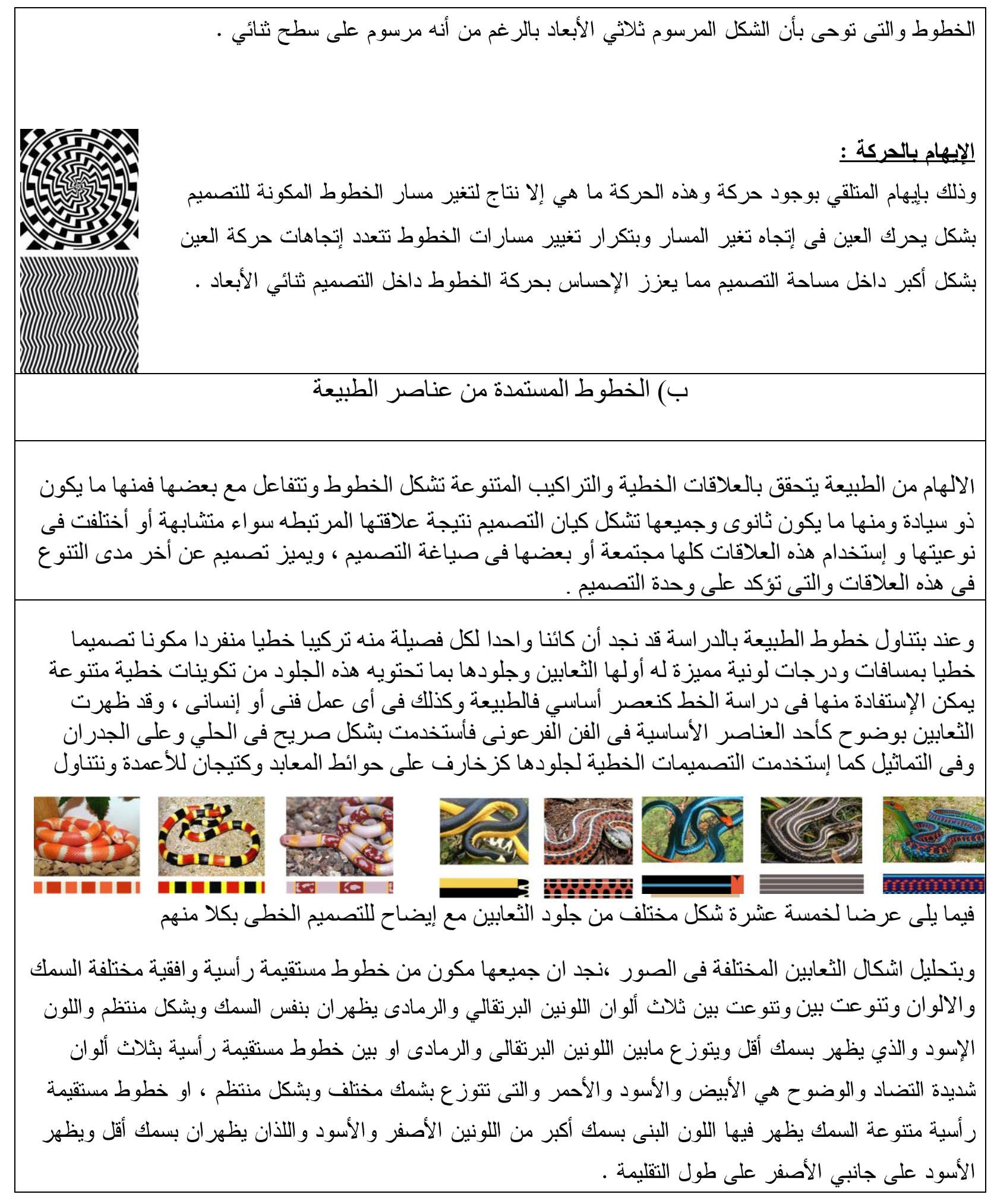



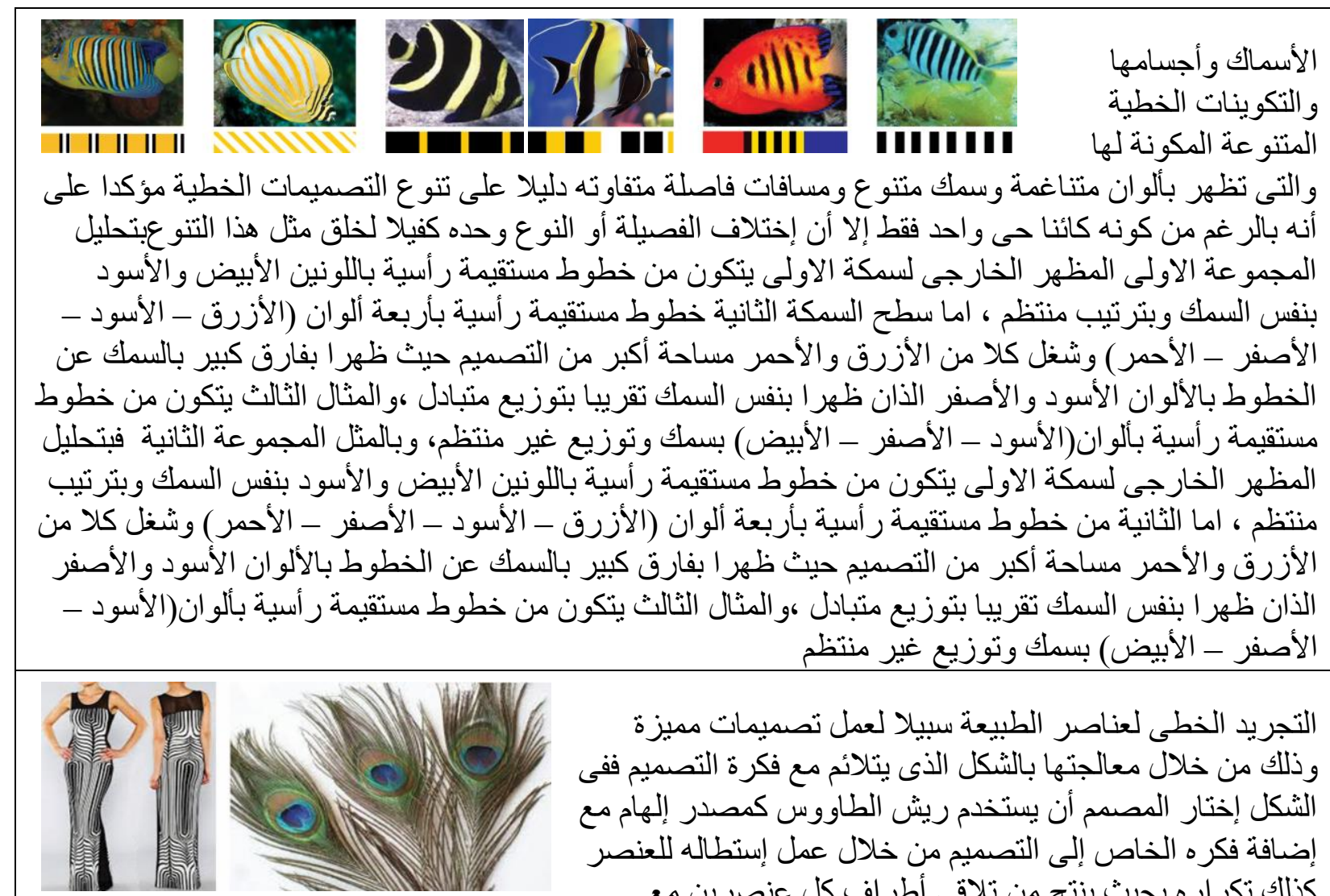

التجريد الخطى لعناصر الطبيعة سبيلا لعمل تصميمات مميزة

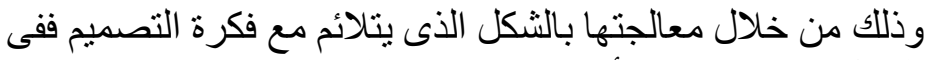

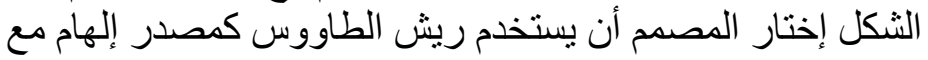

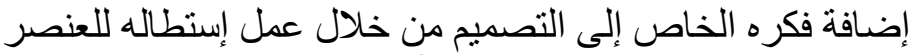

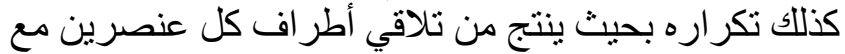
بعضهما البعض علافات خطية جديده تتلائم وطبيعة القطعة الملبسية وتر اعنى أبى أماكن توزبعها فى التصميم .

المحور الثانحى :اساليب التعبيز عن الخط فحى تصميم طباعة المنسوجاث وتصميم الازياء

\begin{tabular}{|c|c|}
\hline تصمبح الازبـاء & تصميح طباعة المنسوجات \\
\hline 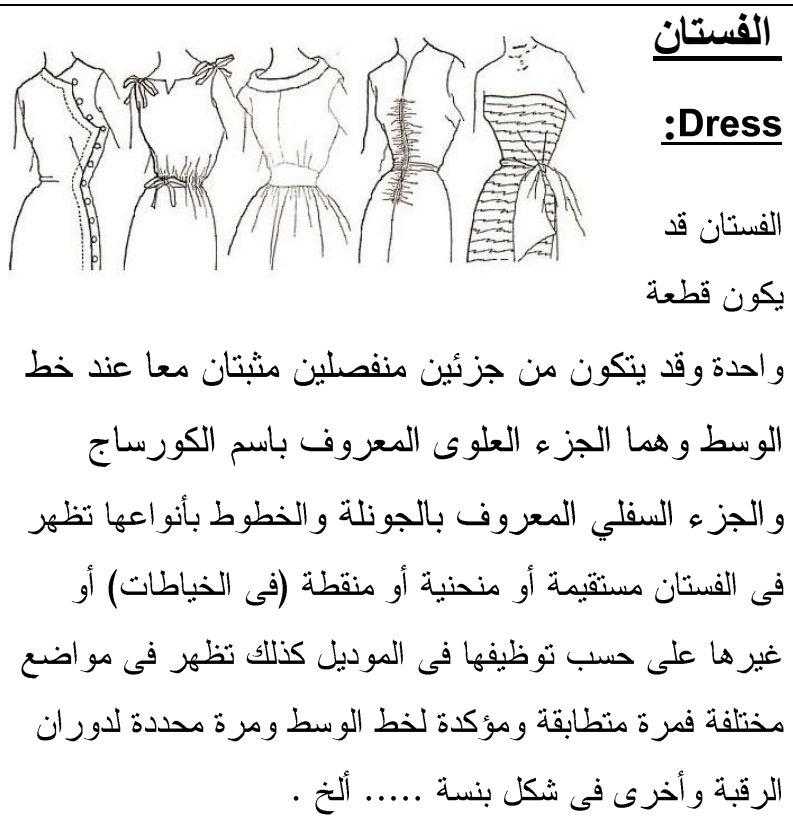 & 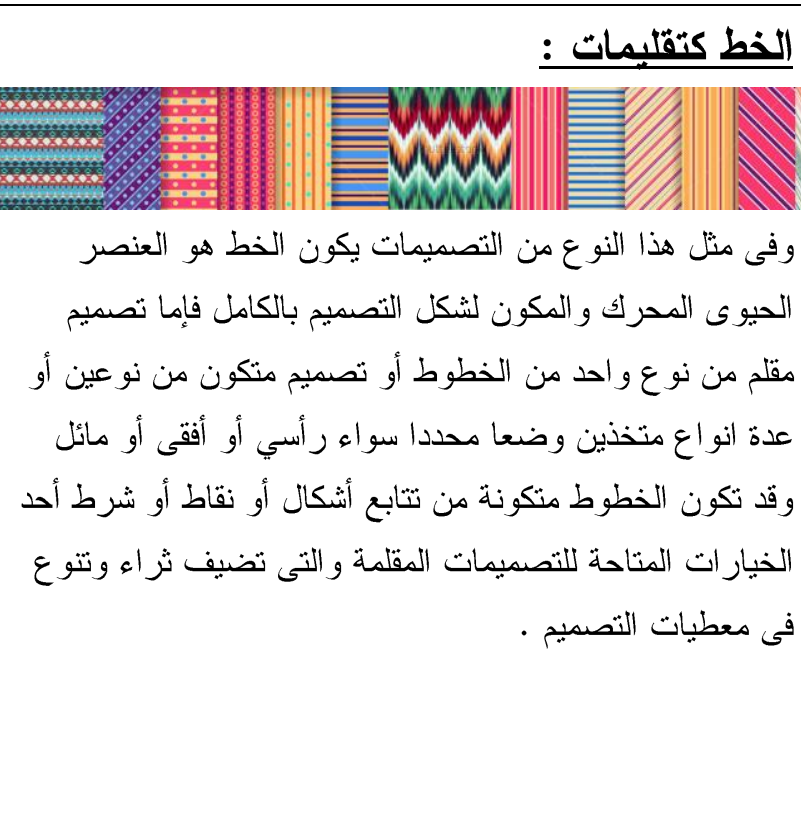 \\
\hline
\end{tabular}




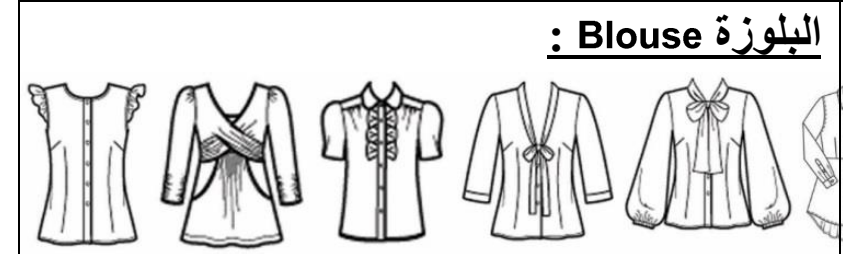

هى قطعة ملبسية بدأت فى تصميماتها متخذة شكل القميص الرجالى فكانت تتميز بوجود كولة ووشاح يشبه رابطه بـات العنق ـ والبلوزة عبارة عن قطعة ملبسية ترتدى من قبل

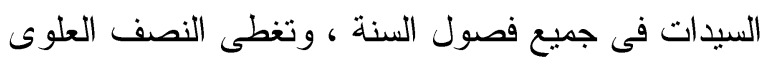
من الجسم وقد تكون بكم طويل أو نصف كم أو بدون أكمام ، و متتوع خطوط تصميمها تبعا لإتجاه الموضة السائدة.

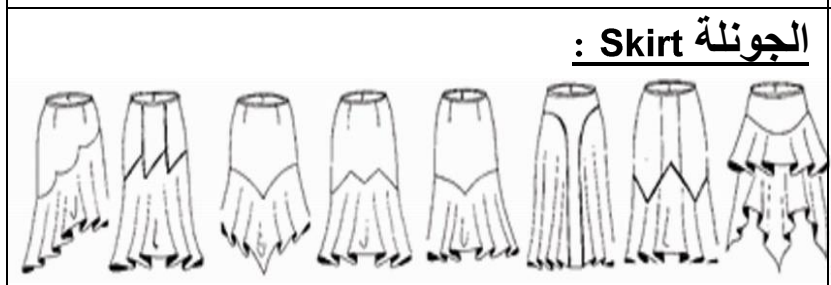

تتميز الجونلة بتصميمات خطية مميزة فما بين الكالوش و الكسر وخطوط القصات التى تنتوع بين الخطوط المقوسة و المنكسرة و المائلة و الحرة و التى تظهر في شكل مكمل لبعضها البعض مع تتوع في خطوط الديل ما بين المائل و الافقي و المنكسر باكثر من طريقة تظهر تتاغما واضحا في التصميم وتضفي العديد من القيم الجمالية

\section{: Trousers (pantaloons) البنطلون}

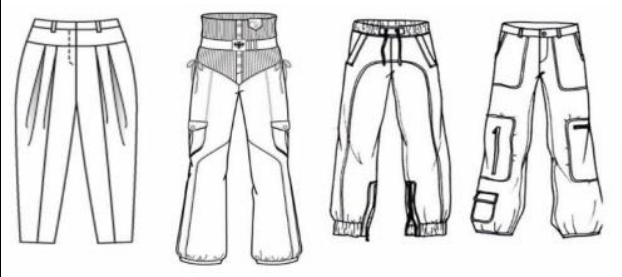

الخطوط فى تصميم البنطلون تترجم في شكل

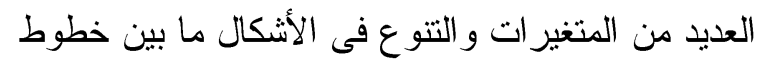

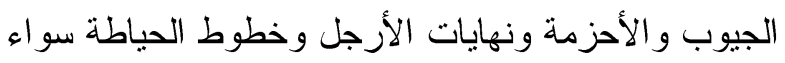

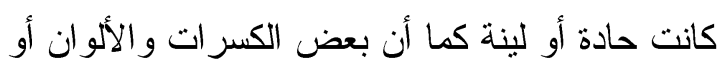
السوست قد تغير من شكل التصميم حيث تكسر الملل و الرنابة وتحقق تتو عاو اضحا

\section{الخط كمحدد للأشكال :}

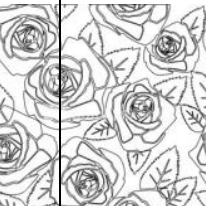

ويظهر الخط فى مثل هذا النوع من التصميمات مترجما للثكل ومجردا له من خلال التعبير عنه بو اسطة الخطوط الأساسية

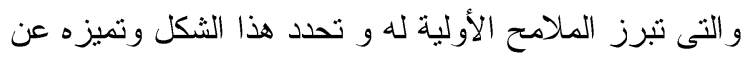

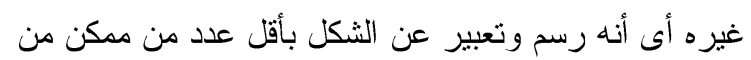

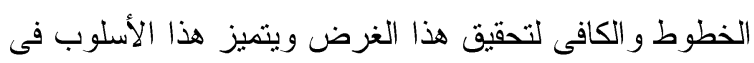

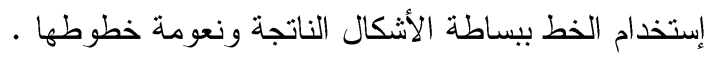
الخط كأسلوب للتعبير عن التفاصيل :
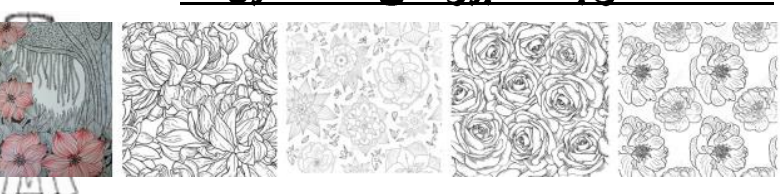

يختلف إستخدام الخطوط كأسلوب للتعبير عن التفاصيل بحيث يجرد كافة تفاصيل الثكل إلى عناصر خطية يمكن التعبير عنها من خلال انو اع واتجاهات الخطوط المختلفة .

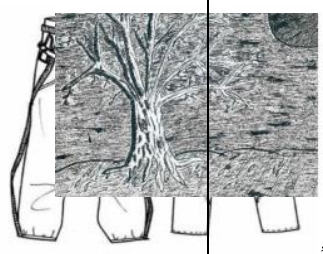

ويعبر الخط عن الملمس من خلال خطوط التهشير أو

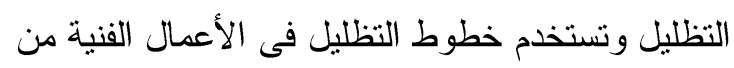
أجل الحصول على تباين وتتوع ولخلق قيم ظلية ، وتختلف

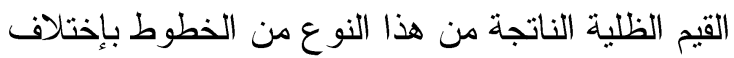

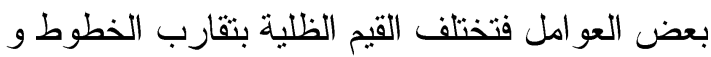

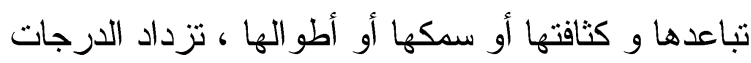

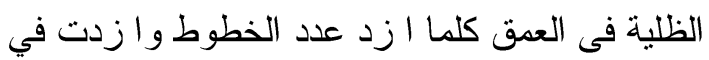
السمك و الكثافة ـ ويمكن الحصول على الخطوط الظلية

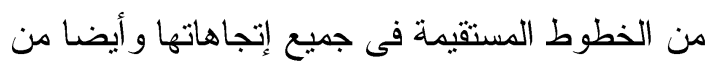




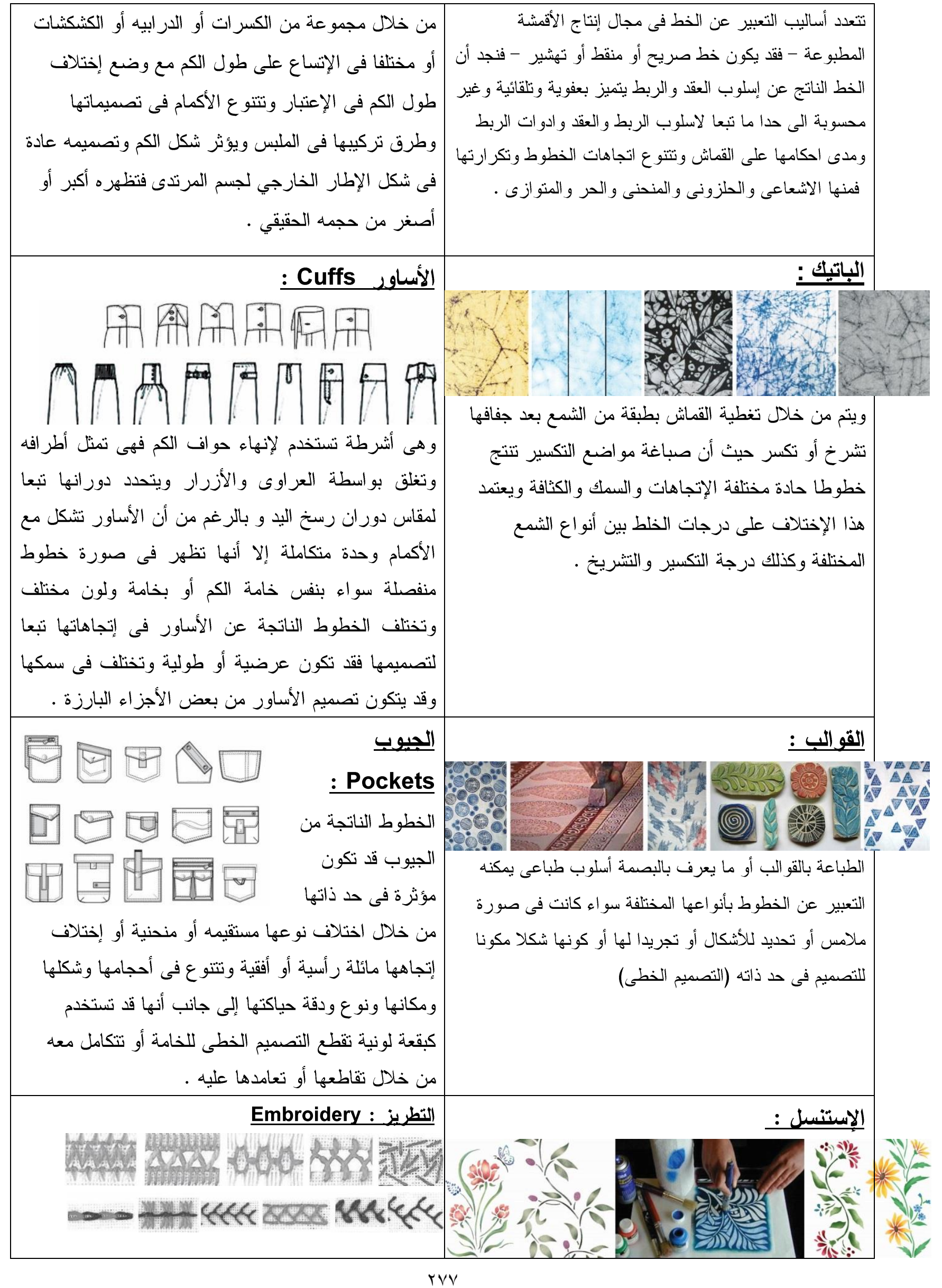


الخطوط الناتجة من زخرفة الأقمشة بالتطريز تختلف فى

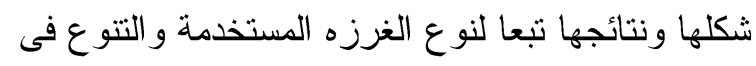
الغرز فى التصميم الواحد و المسافات بين الغرز بعضها لتونها وبعض وتعتبر أهم المعطيات التى تؤثر في النتيجة النهائية للتصميم المطرز هو إستخدام إبر خاصة مختلفة السمك

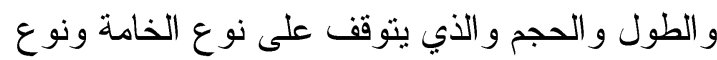

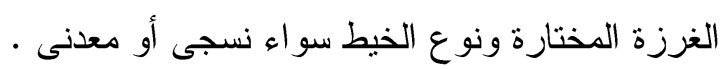

تطبع التصميمات الخطية من خلال تفريغها على ورق مخصص لا ينفذ منه اللون ولا يتشربه ومن ثم طباعة الأماكن المفرغة من خلال الدق بفرشاة مخصصة أو بقطع لهُ لهن صغيرة من الأسفنج وتتيح هذه التقنية حرية فى عدد لهد

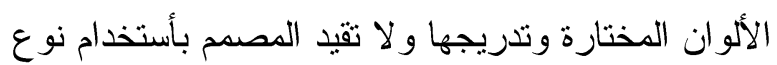
محدد من الخطوط .

\section{المحور الثالث: العلاقة بين التصميم الطباعى وتصميم الزي:}

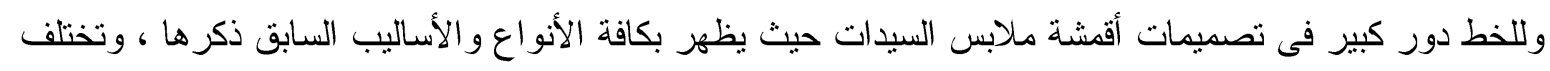
أهمية ودور الخطوط بالتصميم فقد تكون خطوط التصميم بنائية ممنلة لموضوعات ذات طبيعة خطية وهى التى تكون الهيكل البنائي الرئيسي للتصميم أو تكون خطوطا ثانويا وظيفتها الوصل بين تلك الخطوط الرئيسية البنائية وتقوية الر ابطة بينها أو الربط بين أحد الخطوط البنائية وحدود إطار التصميم كى تثير الثعور بالإستمر ار أو اللانهائية ــ وقد لا تكون مجرد حدود خارجية للمساحات بل قد تكون أيضا تحديدا للفو اصل بين مناطق ظليلة واخري شديدة الإضاءة أو كتحديد (v) (للأشكال فى التصميم

و عند وضع تصميم طباعى خطى بهدف إستخدامه فى أزياء السيدات فإنه لا يمكن إغفال الخطوط البنائية للزى نفسه

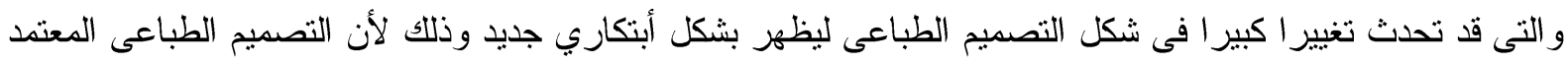

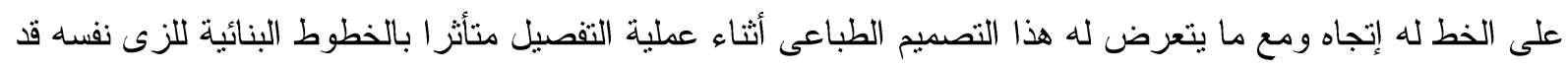

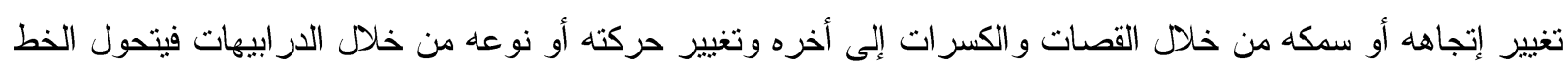
المستقيم إلى خط أكثر ليونة كما بشكل (Y\&) وبذللك فالخط يعد من أقرب العناصر التصميمية التى تساعدنا على دراسة

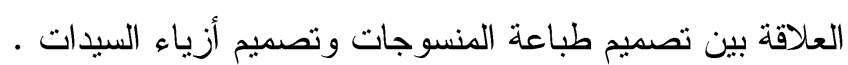

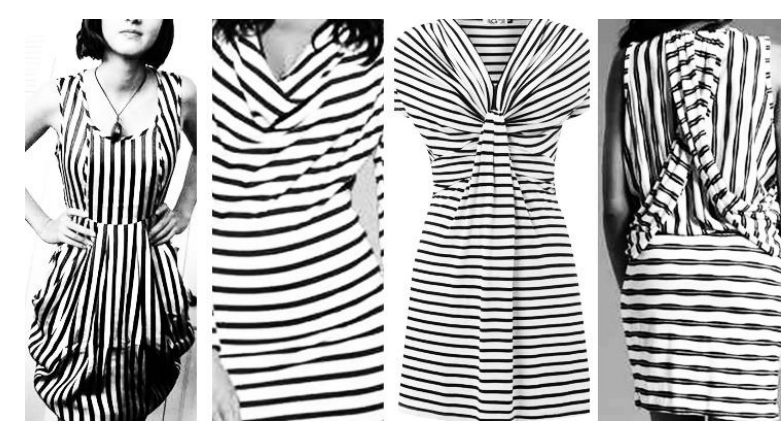

شكل (Y) : يوضح نأثير القصات و الدر ابيهات على نوع الخط و اتجاهه
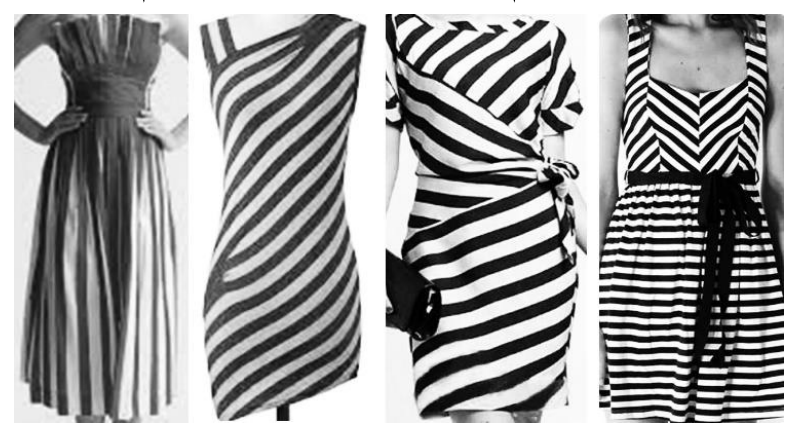

شكل (1) : يوضح تأثثر القصات والكسرات على إتجاهات الخط

لذلك فإن مصمم طباعة المنسوجات يجب أن يمنلك مهارة التقكير في تصميم أقمشة مطبو عة ثنائية الأبعاد تتحول فيما بعد

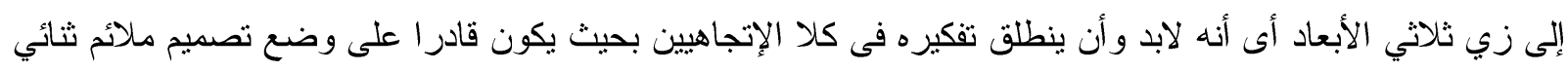

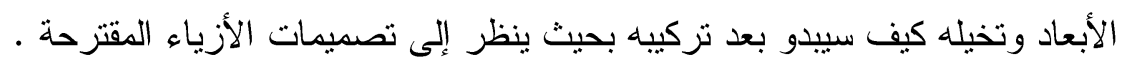


فيكون التصميم الطباعى من جهة وللتصميم الطباعى نوعين أساسيين النوع الأول هو تصميمات القطعة الواحدة أو

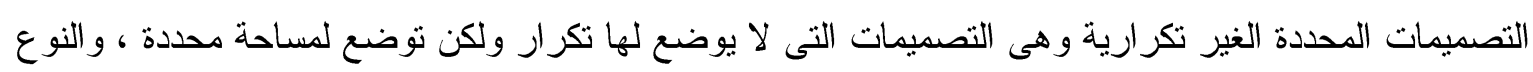
الثانى هو التصميم ذو الإنتاج الكمي ويقصد به التصميم ذو الوحدات المكررة على طول الخامة و الذى يستخدم فى الإنتاج الكمى ونجاح النوع الثانى من التصميمات يتوقف على نجاح التكرار وظهوره بشكل إنسيابي و ذو إيقاع متدفق على طول

(القماش. (^)

وتصميم الأزياء من جهة ممثلا الكيان المبتكر فى خطوطه و مساحاته اللونية وخاماته المتتوعة التى يحاول مصمم

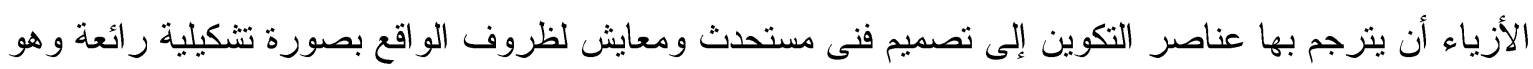

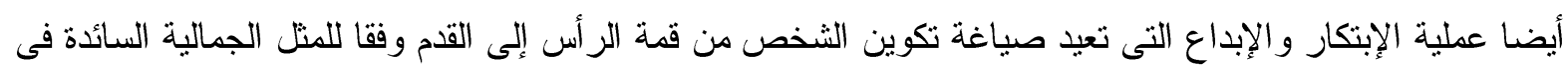

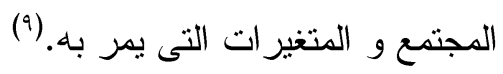

ويمكن عرض الادوار المختلفة للخط في تصميم الزى بتحليل الازياء بالجدول التالي:

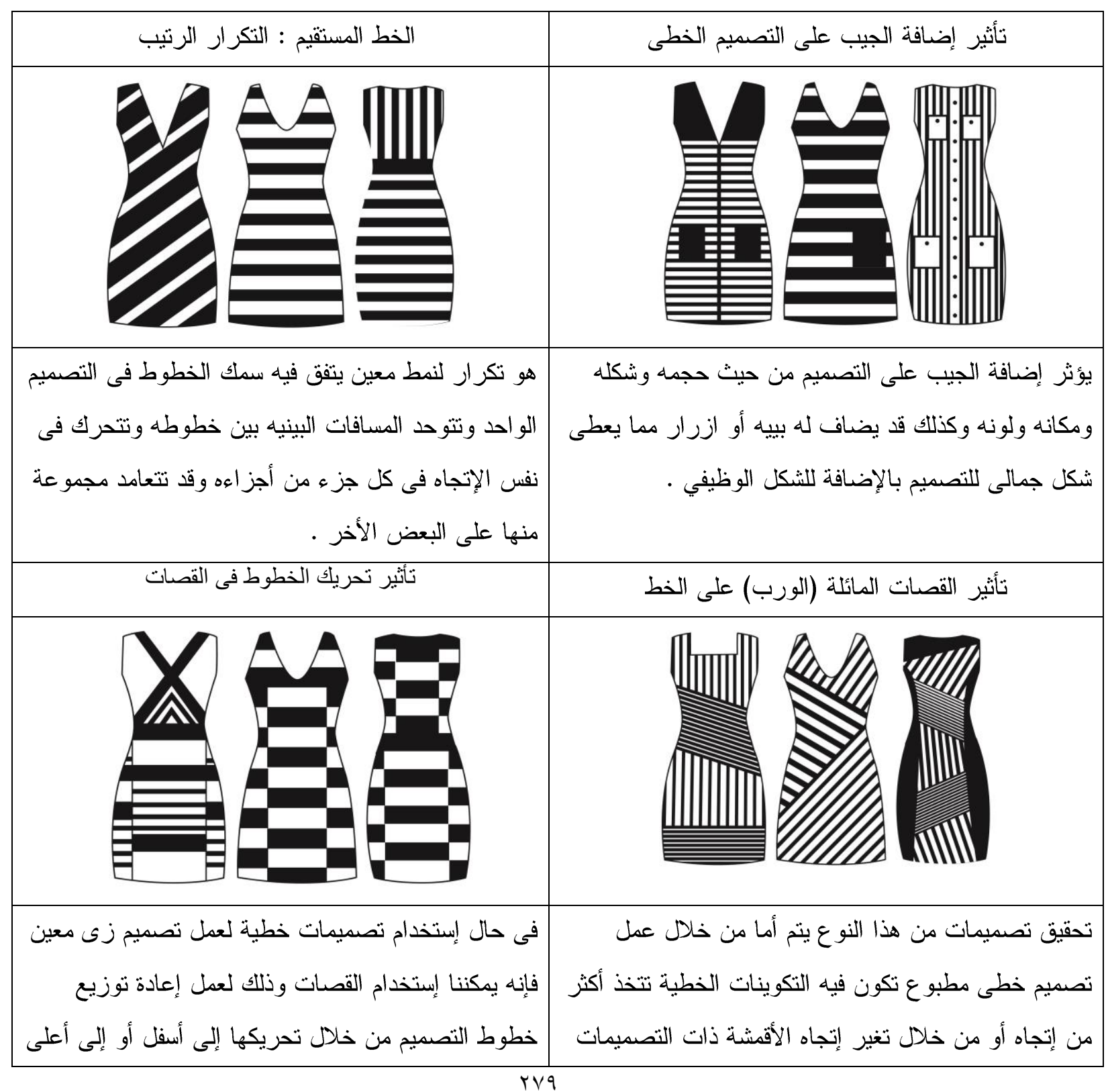




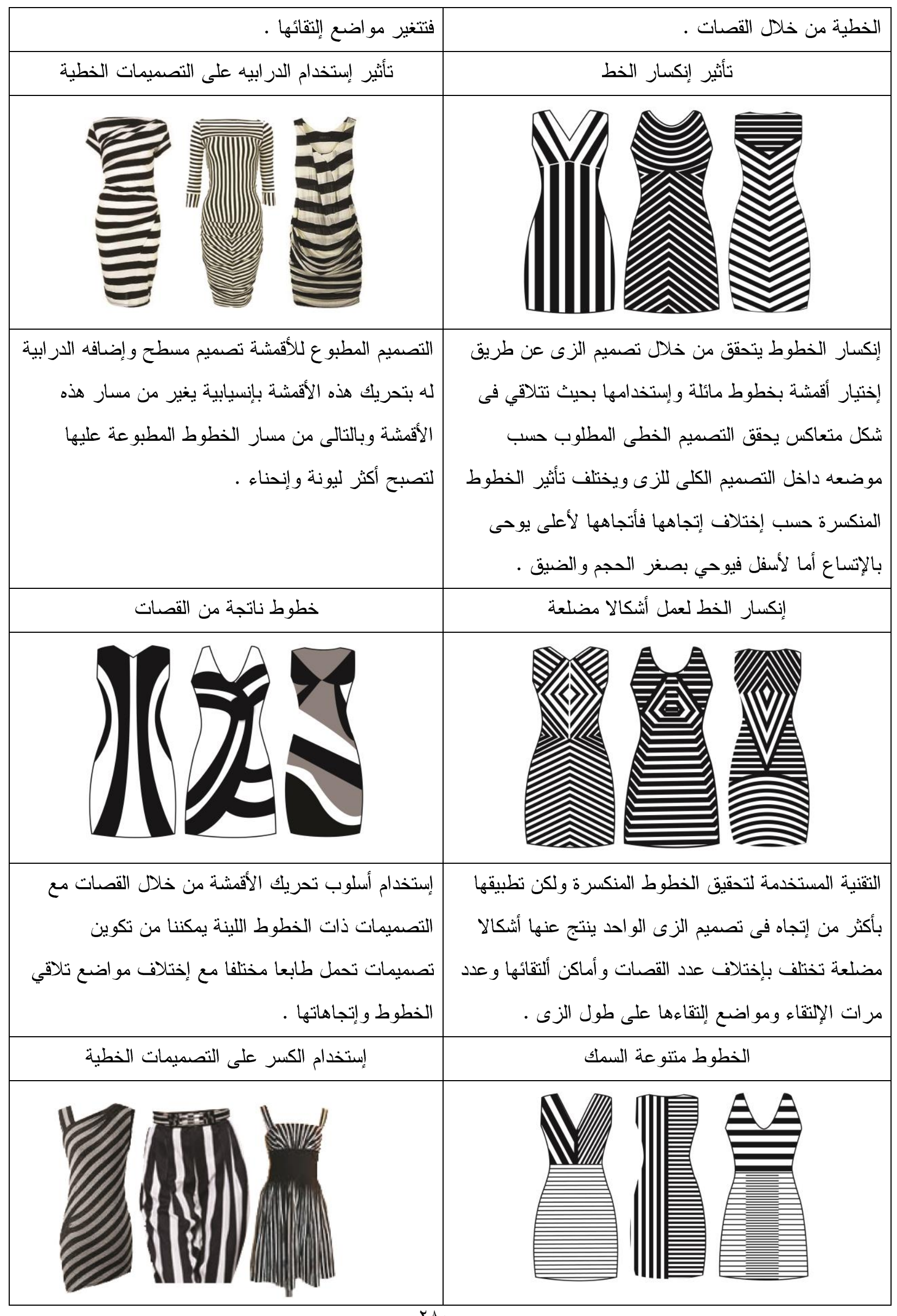




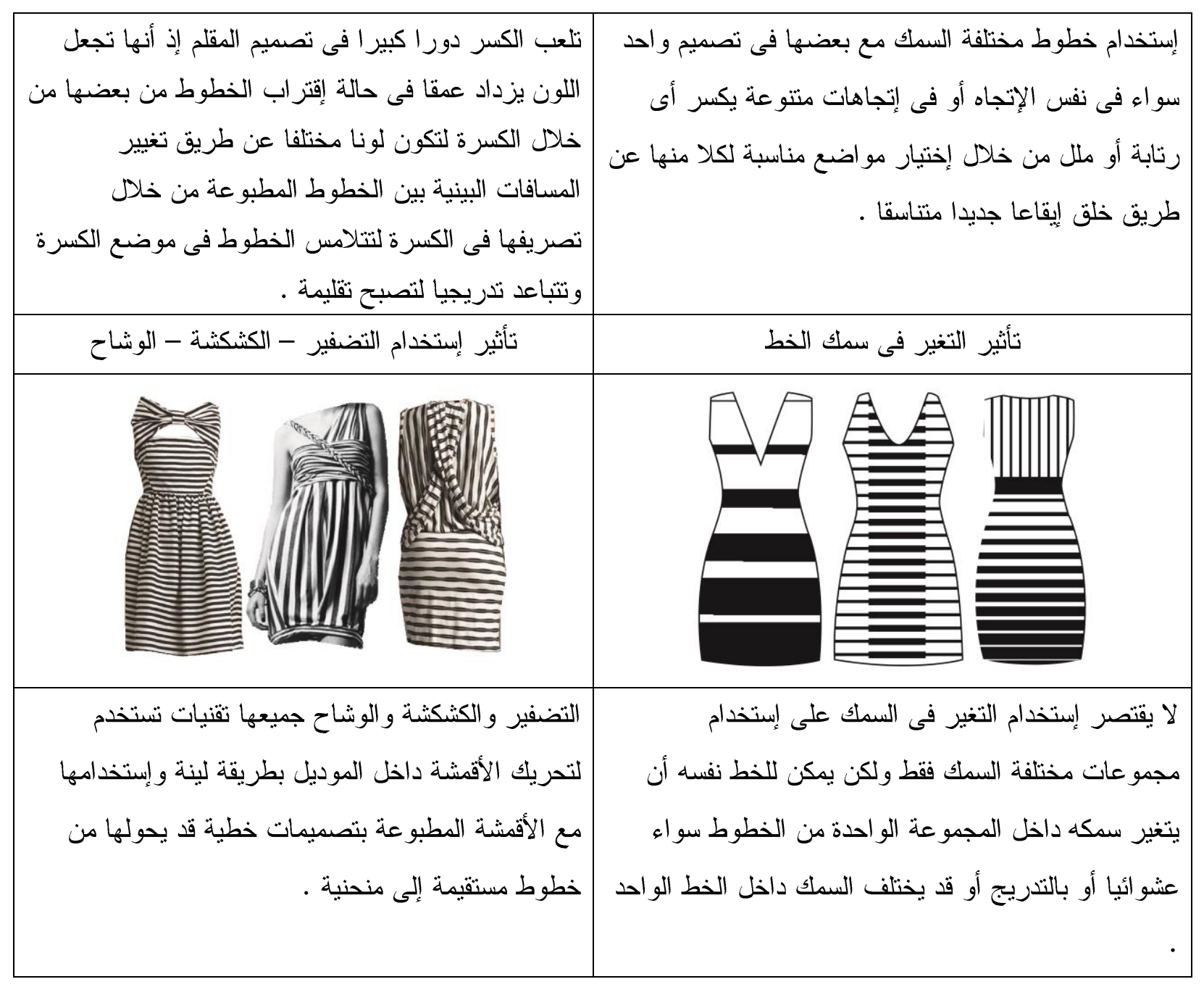

\section{المحور الرابع :مواضع الخطوط ومدلولها (وتاثيرها)في تصميم طباعة المنسوجات وتصميم الازياء:}
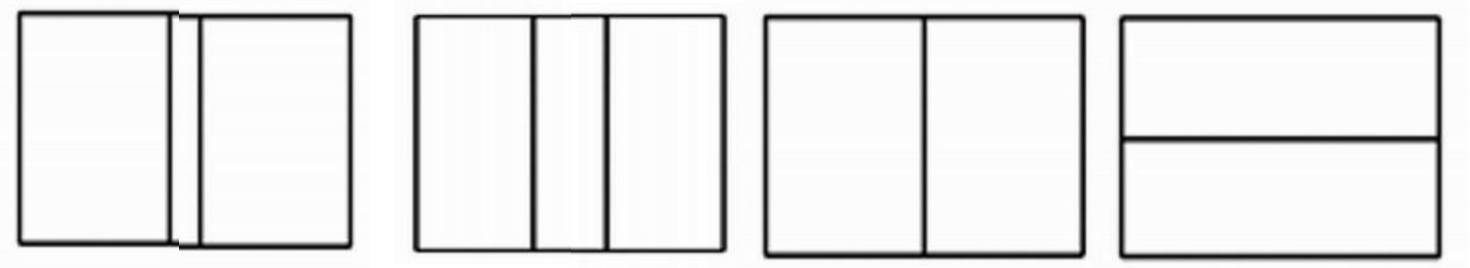

أثز الخطوط فى المستطيلات الاربعة مختلف مع ان مقاساتها واحدة ،فالخط العرضى يظهر المستطيل اقصر من الحقيقة و الخطوط الطولية ،الخط الواحد يظهر المستطيل اطول من الحقيقة ،و الخطوط البعيدة تظهر اعرض من الحقيقة . 


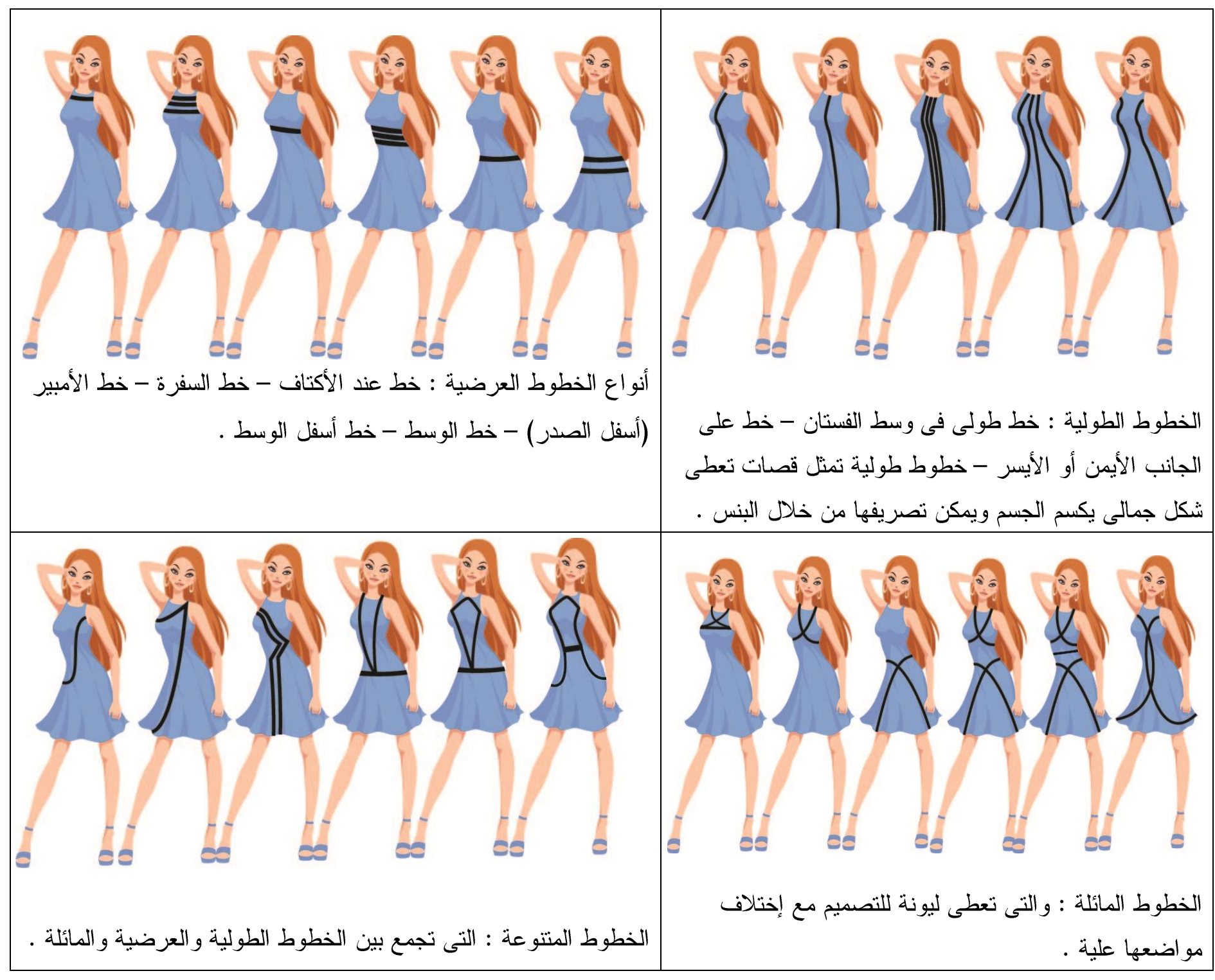

\section{المحور الخامس (التطبيق): تصميمات طباعية وازياء معاصرة مناسبة لانماط الجسم المختلفة :}

\section{تصميمات طباعية متنوعة من عنصر الخط:}

ويمكنا تنفيذ التصميمات الطباعية على الأقششة من خلال صباغة مو اضع محددة لإبتكار أنثكالا وتصميمات على سطح

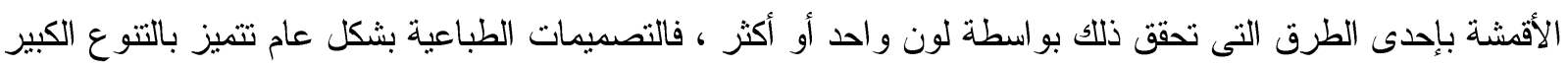

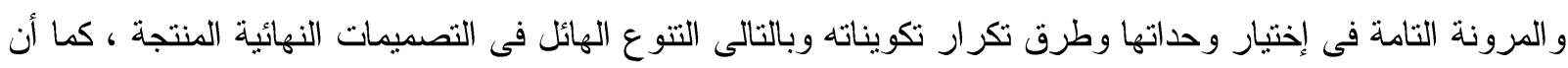

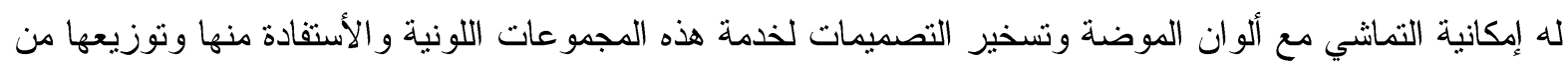

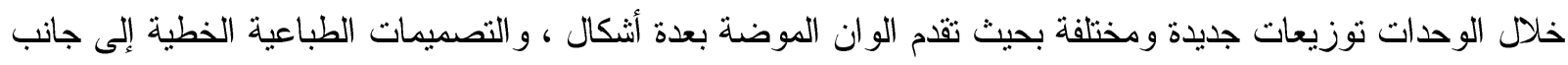

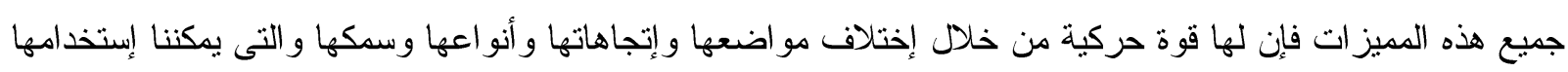

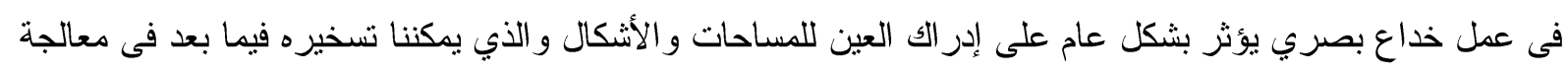

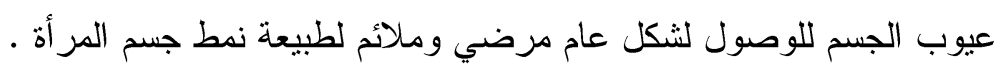




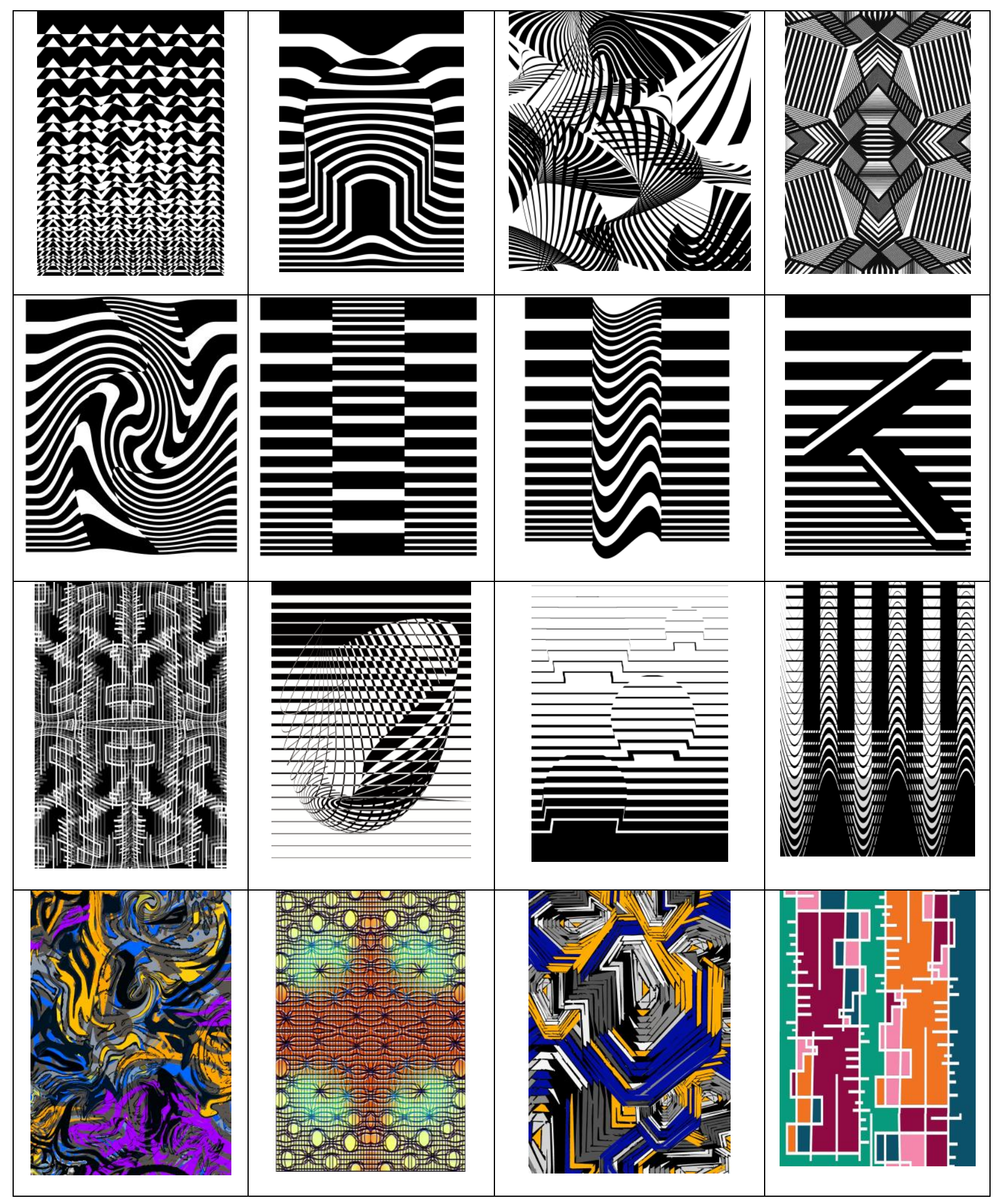

لا يمكن فصل در اسة التصميم الطباعى لملابس السيدات ومتغير اته من الوان ووحدات عن فكرة تصميم أزياء السيدات ومتطلباتها ، كما لا يمكن أغفال تسليط الضوء على الخامات التى سيتم طباعة التصميم عليها وبالتالى يتم تنفيذ الموديل الملبسي من خلالها لما لها من تأثثر على المظهر العام للطباعة وكذلك على شكل الزى النهائي ، فكل هذه التفاصيل

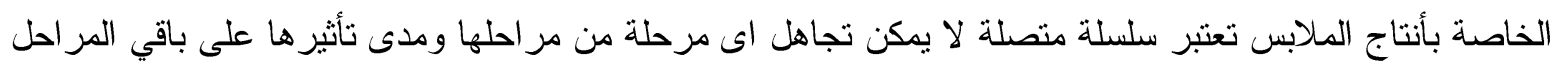

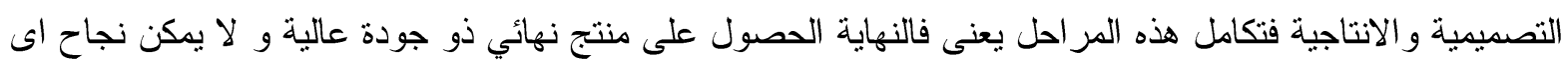


من هذه المر احل منفرده ، ولكن نجد فى النهاية ان ضبط كل هذه المر احل سو اء تصميم أو انتاج لا تعنى بالضرورة

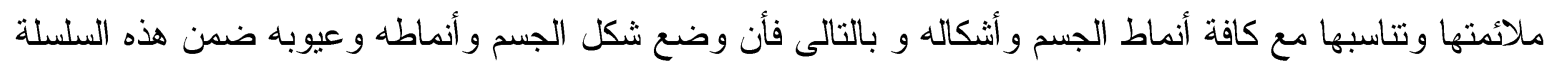
يعزز من فرص نجاح التصميم ويؤثر إيجابيا فى ددى قبول المستهكين المستهفين للمنتج بشكل عام خاصة . فالطريقة الأكيدة التى يبدو فيها نمط الثكل العام للجسم متتاسقا و أنيقا هى أن يكون ذو أتزان مرئي من خلال ملابسه من حيث اللون و الموديل و القماش المستخدم ووحدة الثكل المضافة (التصميم الطباعى) و المتو افقه مع شكل نمط الجسم وصورته. ويتحقق الأتزان المرئي لكل نمط من خلال ملابسه عن طريق الخداع الأدر اكى فى إدرالك الملابس حيث يمكنه أن يغير فى إدر الك الزى وبالتالى يغير فى إدراك نمط الجسم ، فالأبعاد الطبيعية لأنماط الجسم يمكن نوظيفها فى ألتجاه

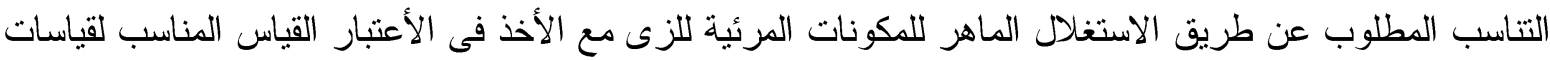
نمط الجسم . (') (1)

لذلك لابد من الحذر فى تتاول تصميمات الخطوط - التى تخلق نوعا من الخداع البصري والادر اكى - لأن الخداع

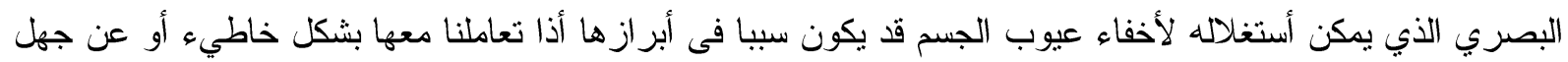
بأمكانياتها .

وتتاسب الملبس مع مقاييس الجسم يتوقف علي رضاء الفرد عنه ، فمها كانت جودة الطباعة من ناحية التصميم و التنفيذ و التثبيت وجوده الملبس من ناحيه التصميم و التفصيل و الحياكه - فان الزى غير المناسب لمقاسات الجسم يكسب نمط فئ

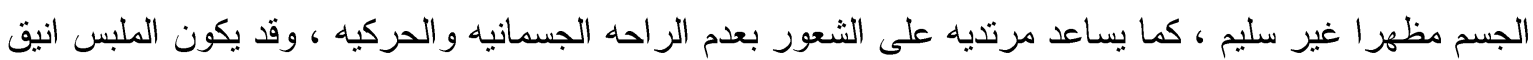
ولكنه غير ملاءم لمقاييس الجسم مما يساعد فى الحصول على مظهر غير لائق •

لذلك فإننا ندرس أنماط الجسم المختلفة بهدف تسجيل نقاط الجسم الجيدة و تحديد النقاط الغير جيدة أو العيوب الجسمانية

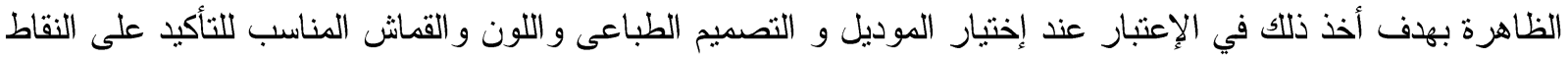
الجيدة الموجبة فى الثكل الظاهرى للجسم و لإخفاء أو للتمويه على العيوب الظاهرة للوصول بالنهاية الى مظهر شخدي ونصي عام أنيق و جذاب من خلا إظهار أفضل القيم الجمالية للجسم. ويمكنا عرض الأنماط الأساسية لجسم المرأة من خلال تصنيفين أساسبن : التصنيف الأول :

توصل شيلدون بناء على مجموعة من القياسات الجسمية من : محيط الرسغين ، الساقين ، الركبتين ، الساعدين ،

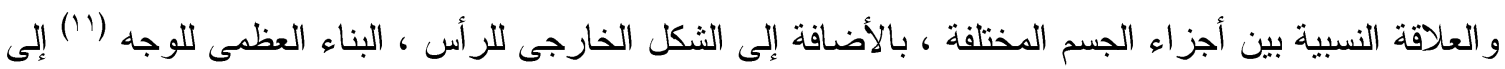
تصنيف أجسام المر أة من حيث الحجم و التكوين البنائي إلى ثلاثة أنماط أساسية 


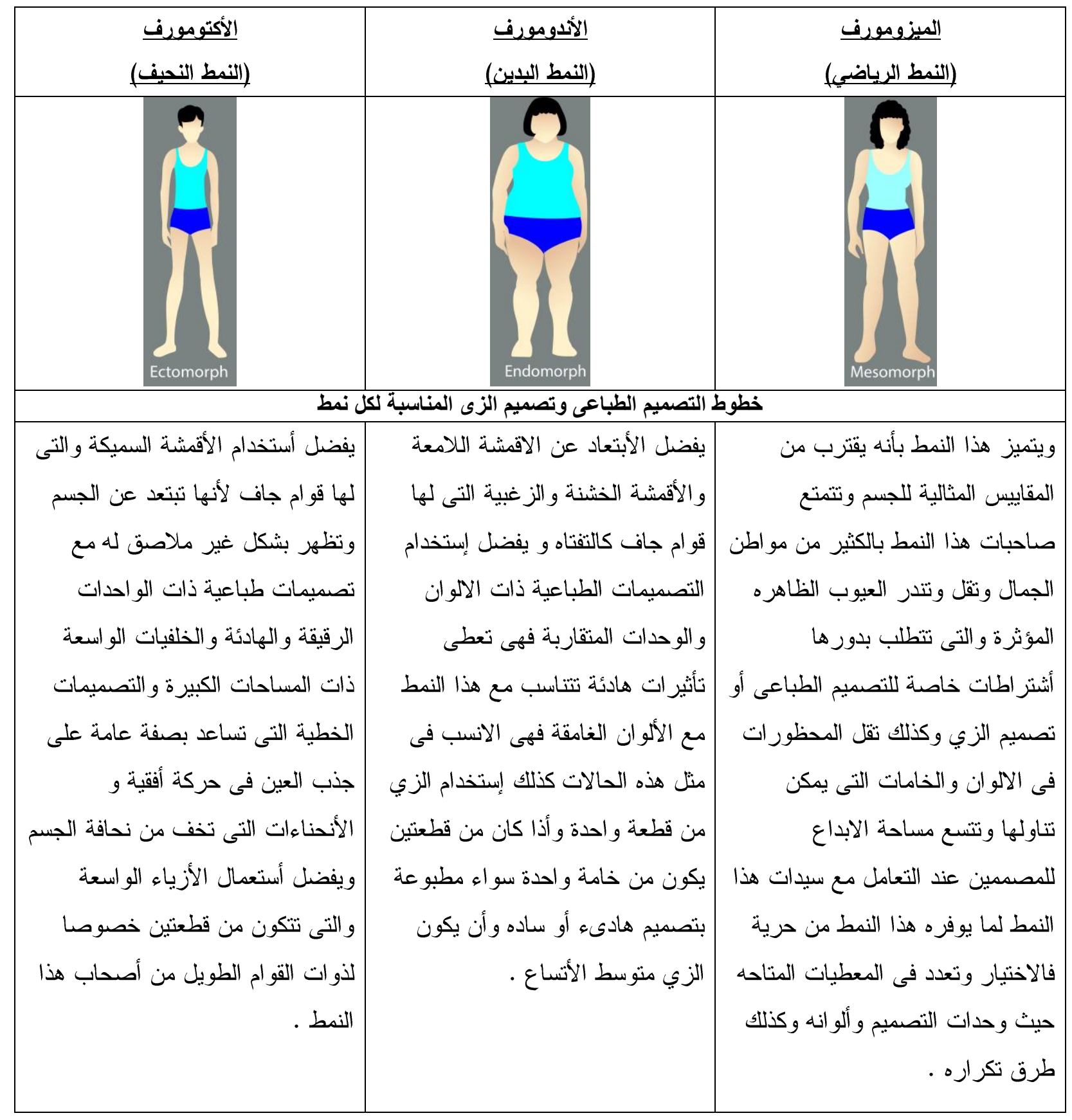

ومن خلال هذه التجربة يمكننا قياس مدى تأثثر خطوط التصميم الطباعى على معالجة انماط الجسم موضع التجربة (نمط

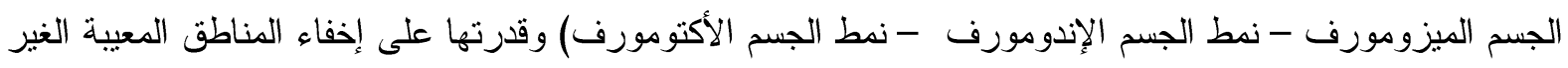
مرغوبة و إبراز مو اطن الجمال وذلك مع تتبيت خطوط تصميم الزى المستخدمة فى التجربة لكل الأنماط .

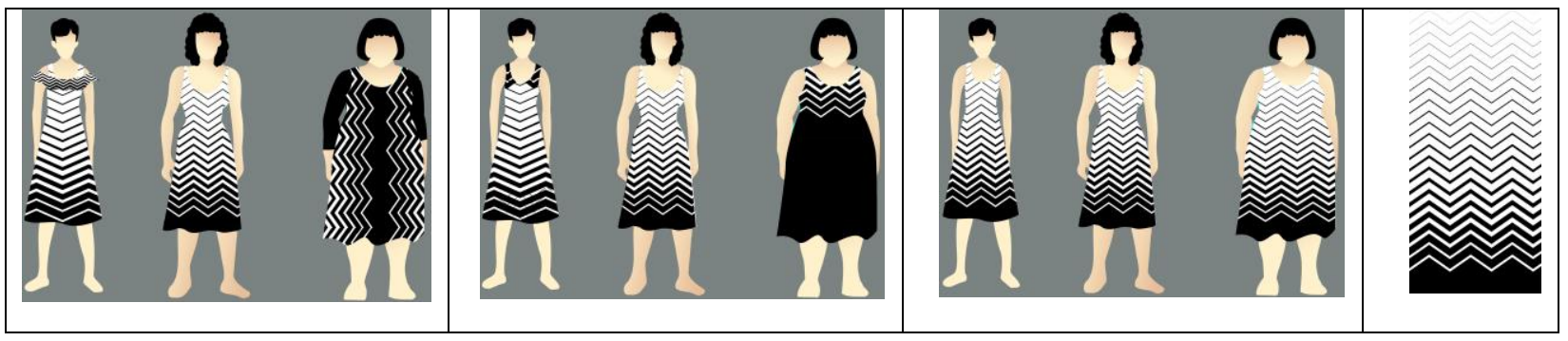

rNo 


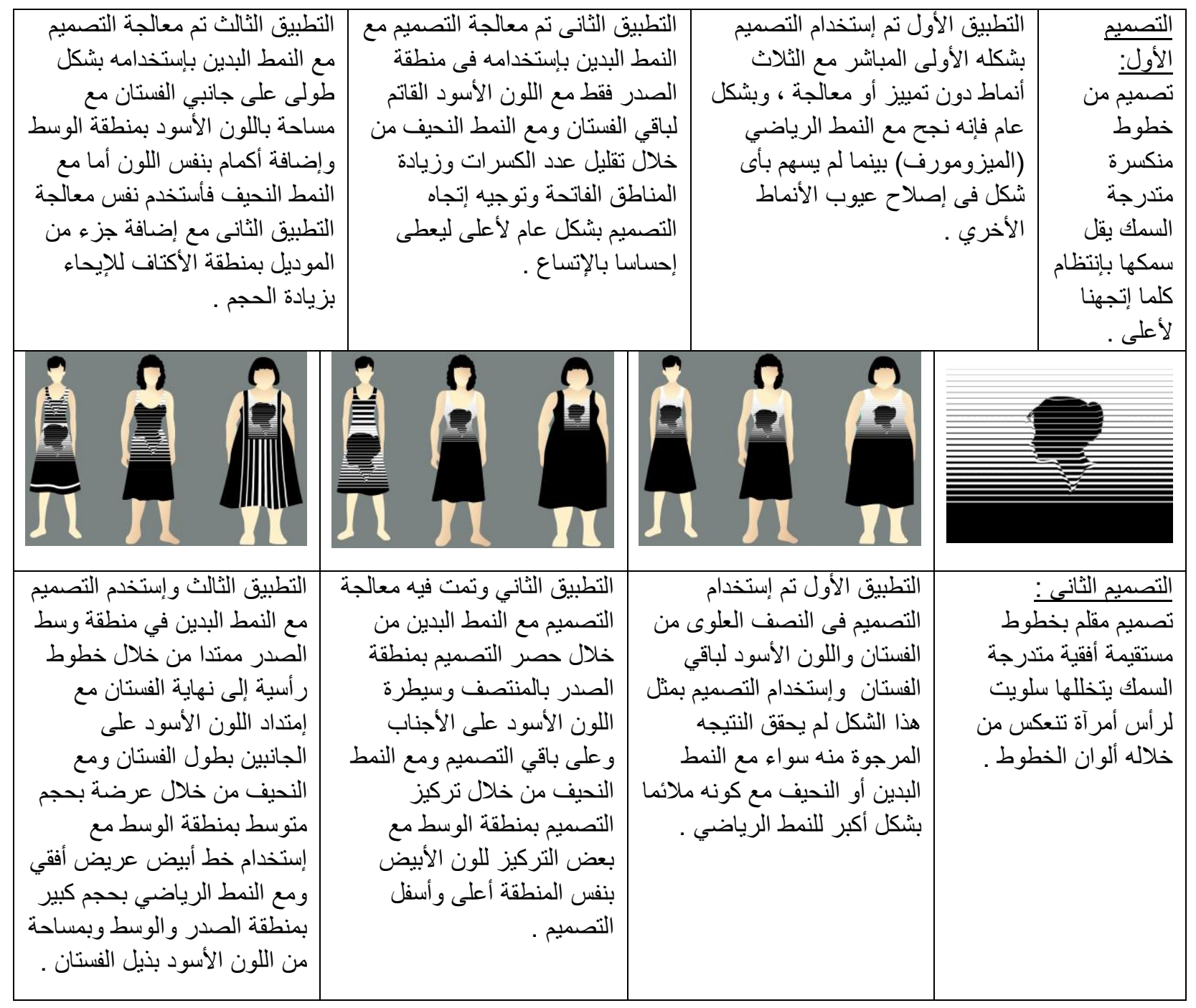

\begin{tabular}{|c|c|c|c|}
\hline التطبيق الثالث و تمت فـه معالحة & التطسة الثان و تمت فـه معالحة & التطبق الأول تم استخداد & التصمد الثالث \\
\hline التصميم من خلال أضافة & التصميم مع النمط البدين من & التصميح بشكل أولى وبحجم & تصميح مقلم بخطوط \\
\hline مساحات من اللون الأسود على & خلال تركيز اللون الأسود على & واحد تقريبا مع كل الأنماط & منحنية رأسية و أفقية \\
\hline الجانين بحيث تزيد مساحتها & الأجناب وحصر التصميم بالأتجاه & سواء بدين أو نحيف أو رياضي & متقاطعة تختلف فى \\
\hline بمنطقة الوسط وعرض التصميم & الطولي أما مع النحيف فتم & ومن أنجح الأنماط مع هذا & درجات أستقامتها \\
\hline بشكل أصغر بخطوط متجهة & التركيز على المنحنبات و إستغلال & التطبيق هو النمط الرياضي & و أنحنائها على طول كل \\
\hline للاخل لتقليل الحجم أما مع النمط & مساحات أكبر من اللون الأبيض & حيث يخدمة التجانس بين & خط كما تختلف المسافات \\
\hline النحيف فكان أساس المعالجة & مع بعض المساحات الصغيرة من & المساحات باللون الأبيض & البينية بينها وتتتوع فى \\
\hline التركيز على الخطوط المنحنية & الأسود على الأجناب و الوسط & و الأسود مع المنحنيات . & السمك بشكل كبير \\
\hline بالنصف العلوى من الجسم & ومع الرياضي بتوزيع مختلف & & \\
\hline و الرأسية بالسفلي مع زيادة & لالتقساحات الألوان وتقليل عدد & & \\
\hline & & & \\
\hline
\end{tabular}




\begin{tabular}{|c|c|c|c|}
\hline 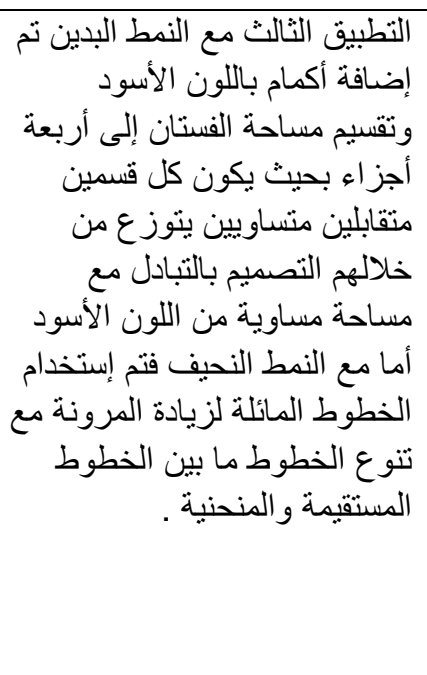 & 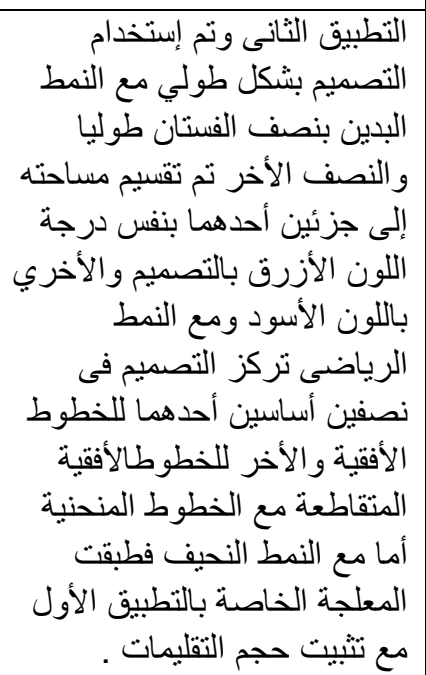 & 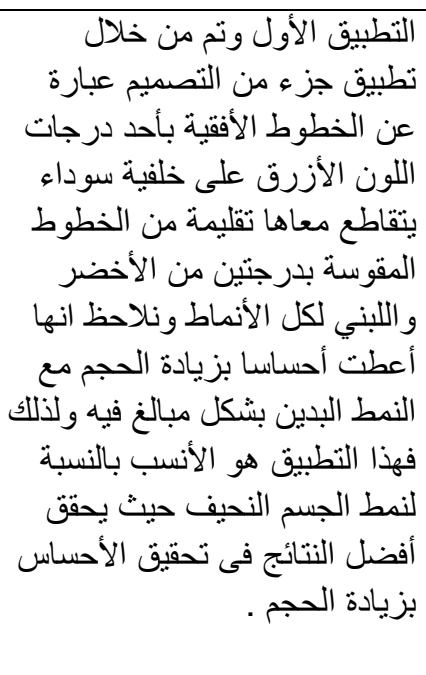 & 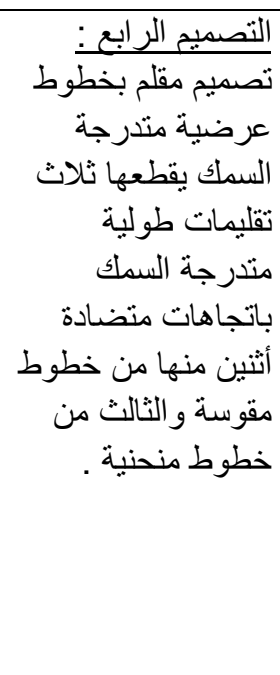 \\
\hline
\end{tabular}

ومن خلال هذه التجارب يمكننا ملاحظة أن معالجة عيوب النمط النحيف تتطلب إستخدام خطوط الزى بشكل أكبر لعمل قصات وموديلات لها حجم وأرتفاع مؤثر كالدر ابيهات و الكر انيش وغيرها من التفاصيل التى تزيد من الحجم العام و المساحة الكلية للجسم وبالتالى تعالج نحافة أماكن الجسم المختلفة أما فى النمط البدين فالتصميمات الطباعية ذات الأتجاهات الطولية والألو ان القاتمة و الموديلات البسيطة تكون أنسب الحلول المتاحة للوصول لمظهر عام أفضل .

ثاتبا : تقسبي أثنكال جسم المر أة إلى أثنى عشرة نمط Trinny \& Susannah وفيه يتم تقسيم أنماط الجسم إلى أثنى عشر نمط يحاول من خلالها عرض أكثر أثنكال جسم المر أة شيو عا وأهم عيوبها

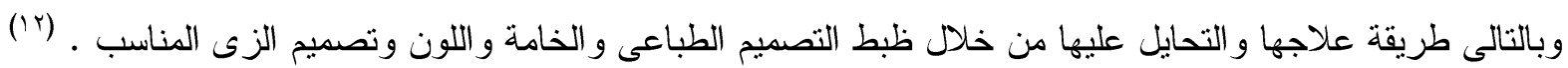

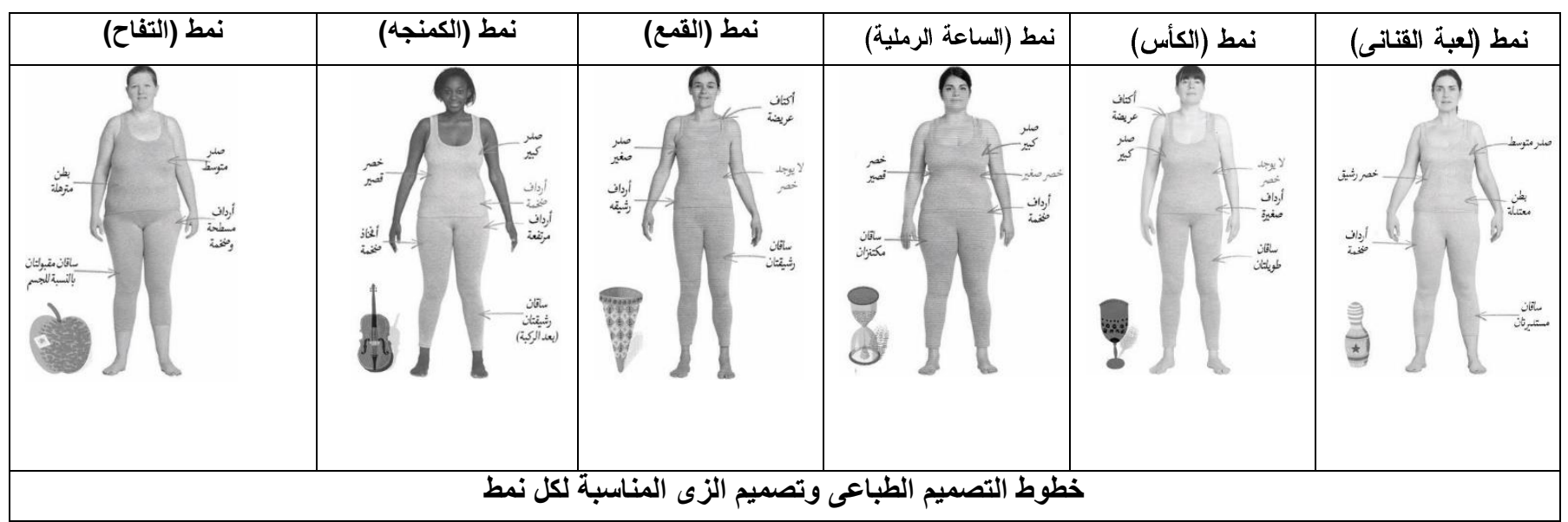




\begin{tabular}{|c|c|c|c|c|c|}
\hline 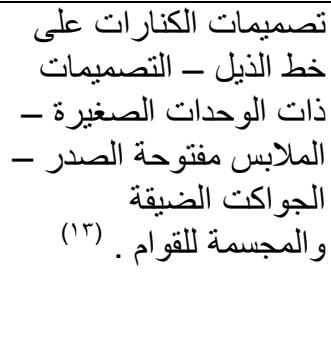 & 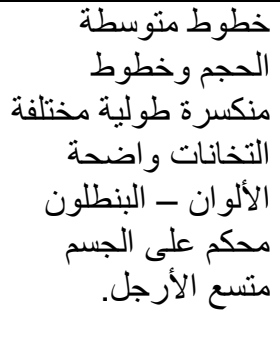 & 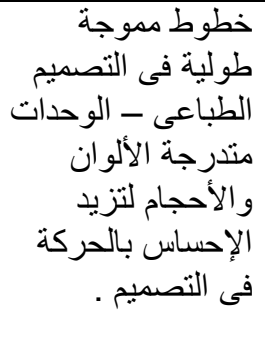 & 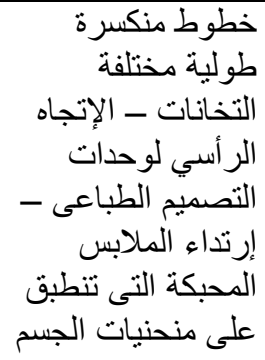 & 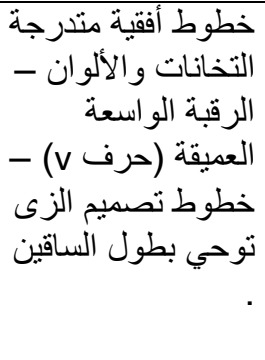 & 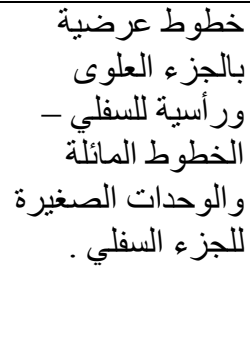 \\
\hline نمط (الكمترى) & نمط (المصاصة) & نمط (القالب) & نمط (الفازة - الزهرية) & نمط (الجرس) & نمط (العمود) \\
\hline $2 B$ & () & 1 & | & $\sqrt{2}$ & تشئت \\
\hline \multicolumn{6}{|c|}{ خطوط التصميم الطباعى وتصميم الزى المناسبة لكل نمط } \\
\hline 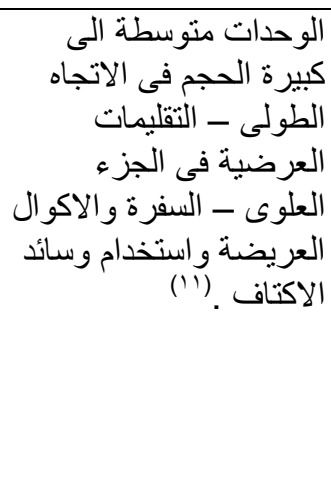 & 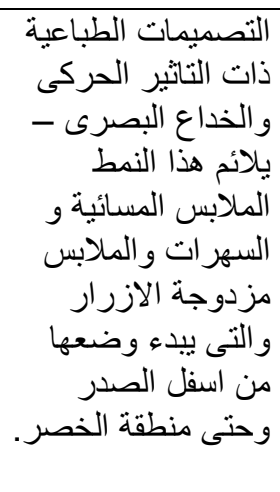 & 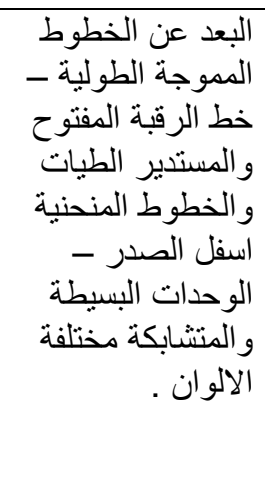 & 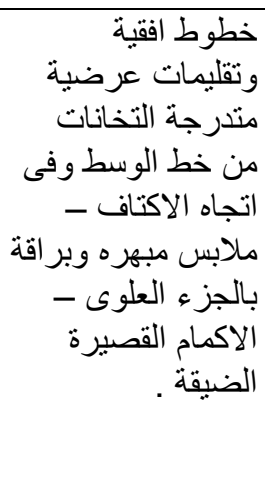 & 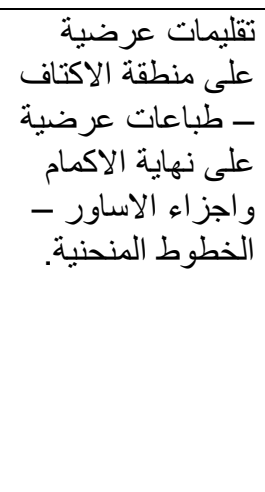 & 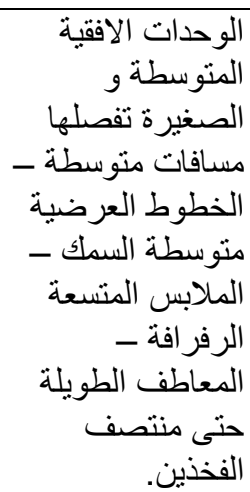 \\
\hline
\end{tabular}

ومن خلال هذه التجربة يمكننا قياس مدى تأثير خطوط تصميم الزى على معالجة انماط الجسم موضع التجربة (نمط الجسم الكمثري - نمط الجسم القالب - نمط الجسم الساعة الرملية) وقدرتها على إخفاء المناطق المعيبة الغير مرغوبة و إبراز مو اطن الجمال.

\section{تصميمات ازياء معاصرة مناسبة لنمط الجسم الكمثرى :}



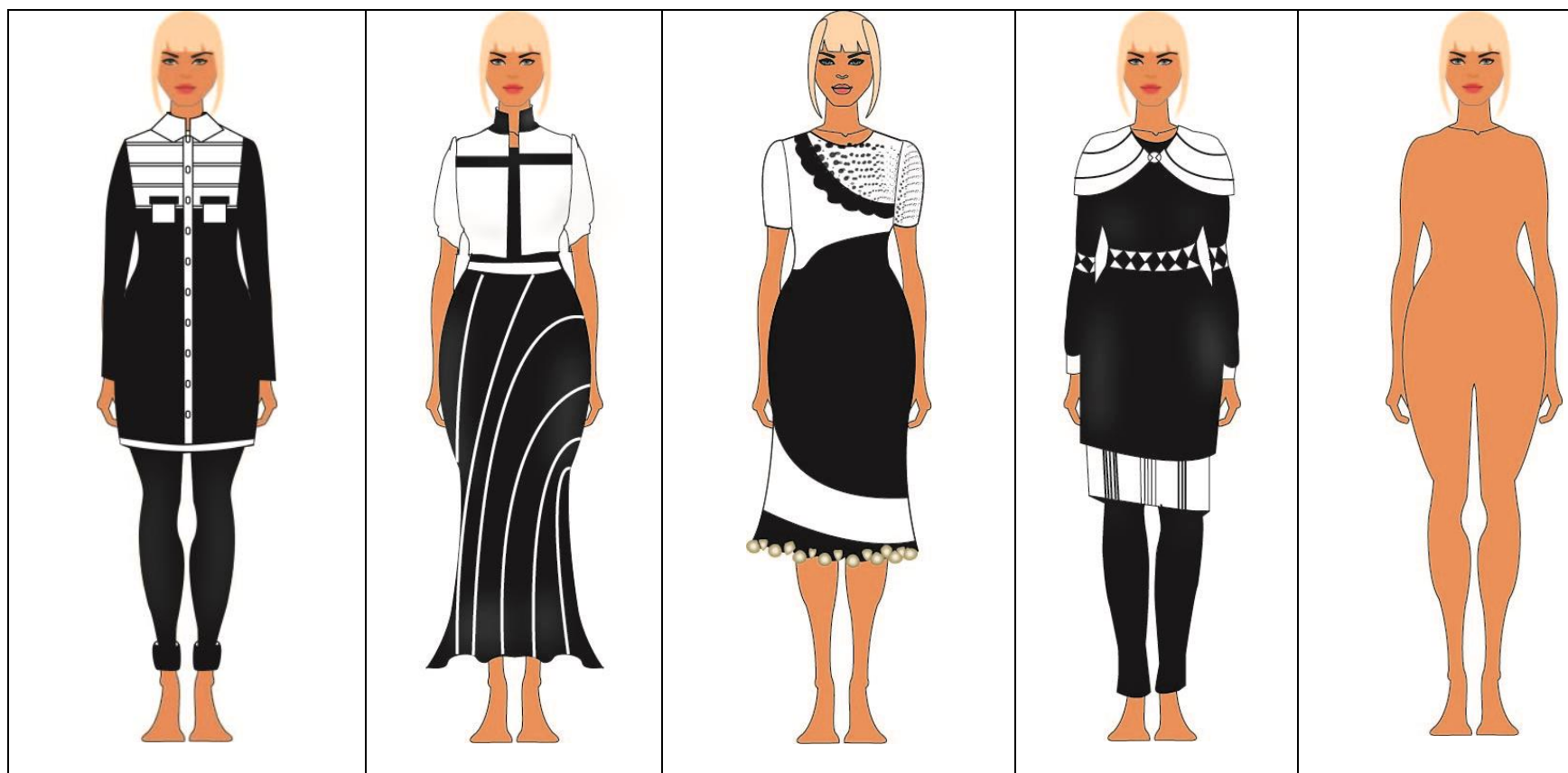

- خطوط تصميم الازياء المناسبة لهذا النمط هو إبتكار تصميمات تساعد على إظهار جمال الجزء العلوى من الجسم مثل خط الرقبة المفتوح

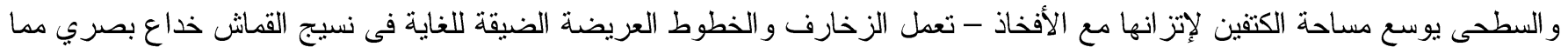
يوحى بجسد أكثر أنوثة - إبعاد النظر إلى الأرداف العريضة الممتلئة و الساقان المكنتزة.

\section{تصميمات ازيـاء معاصرة مناسبة لنمط الجسم القالب :}

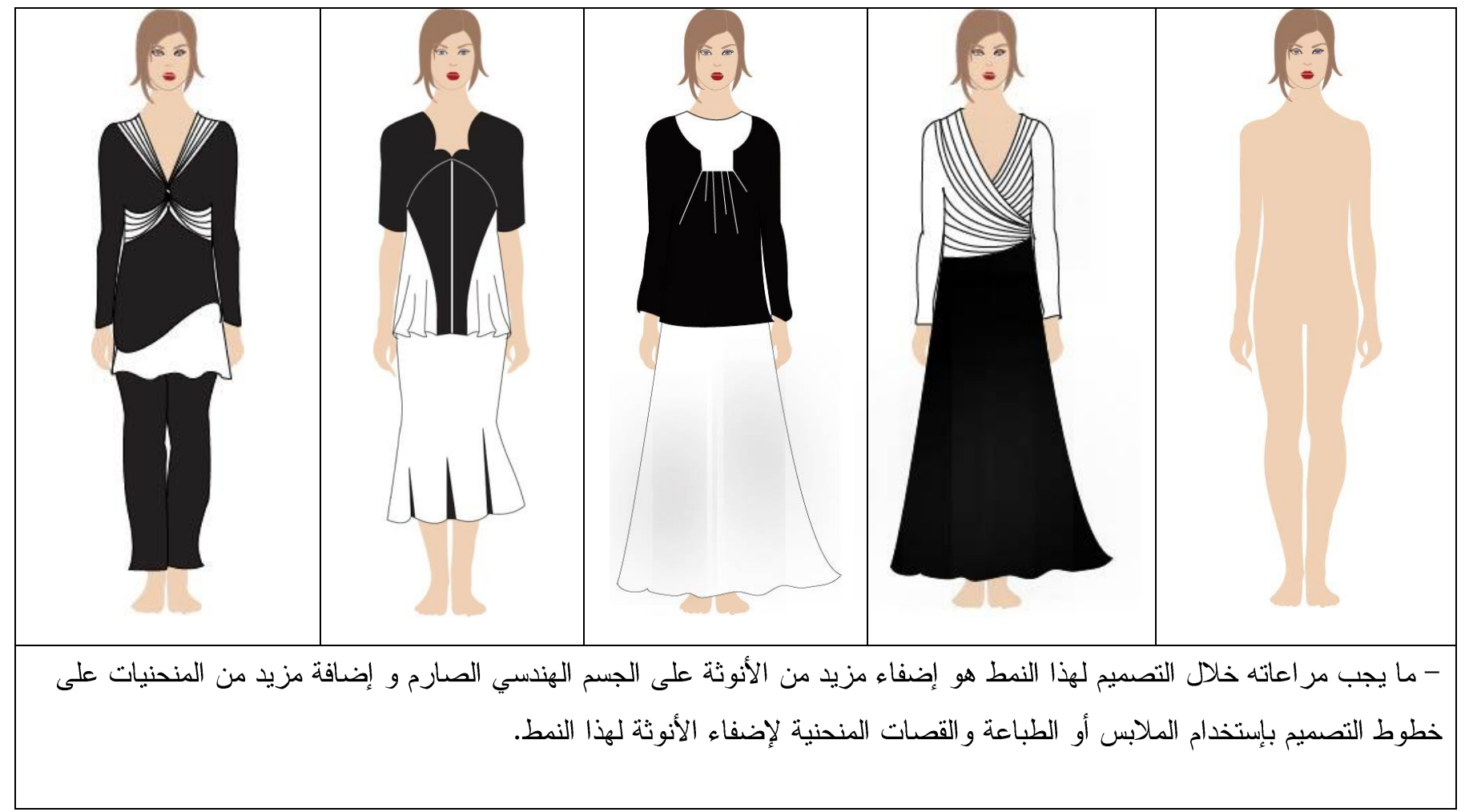

\section{تصميمات ازياع معاصرة مناسبة لنمط الجسم الساعة السياعة الرملية :}




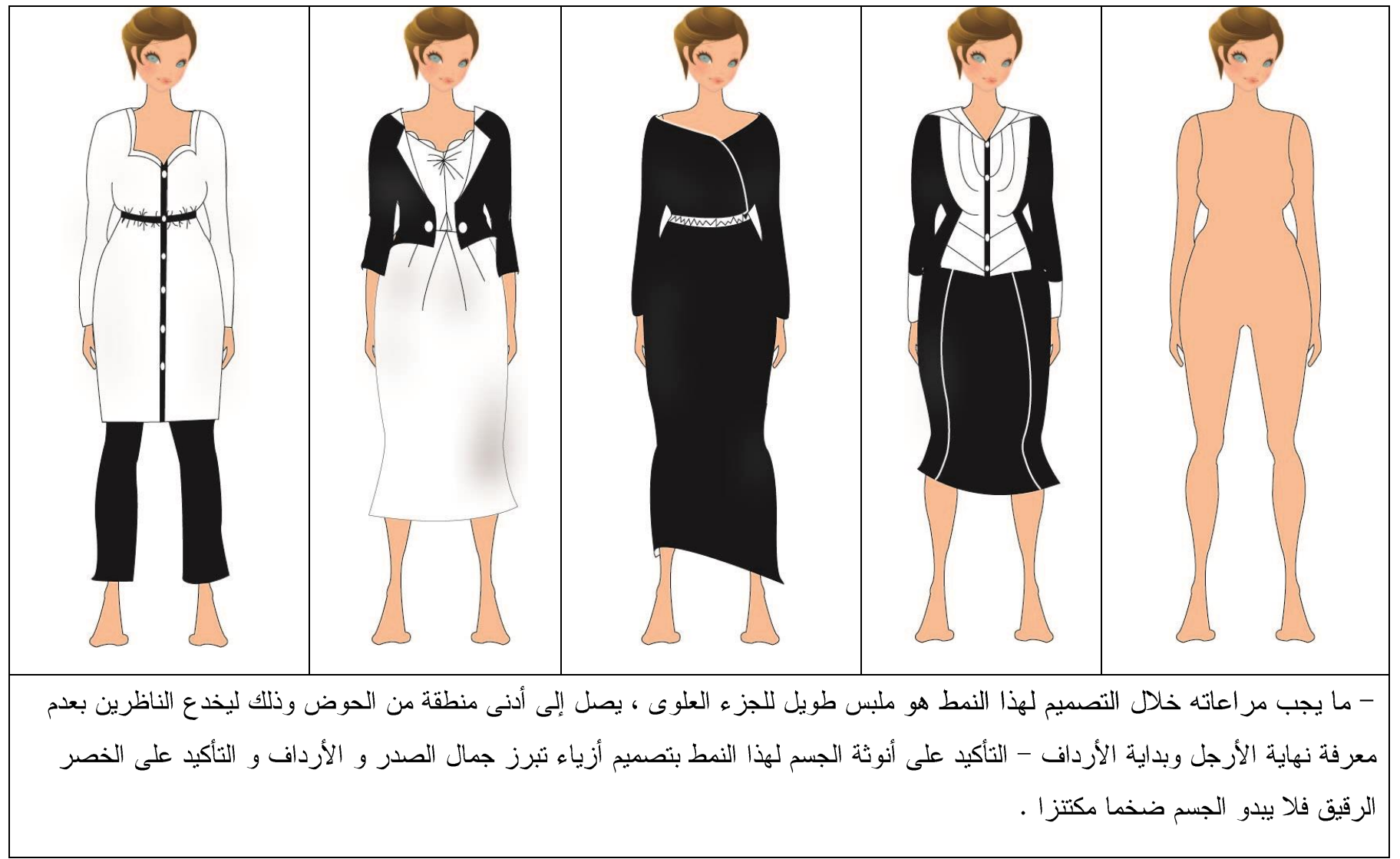

النتائج :

- كلما تتو عت خطوط التصميم الطباعى وزاد مستوى الفكر و الإبداع و الإبتكار بها كلما تتحى تصميم الزى وكان من الأفضل إختز ال خطوطه .

- أذا كانت خطوط تصميم الزى و اضحة ومبتكرة (كر انيش - در ابيهات - كسر ......) وتلعب أدو ار ا محورية فى التصميم المتكامل للمنتج النهائي فإن خطوط التصميم الطباعى تكون أبسط ما يكون للحفاظ على الشكل العام و الوصول للنتيجة المرغوبة . - إستخدام الخطوط (خطوط التصميم الطباعى - خطوط تصميم الزى) فى معالجة عيوب جسم المر أة طبقا للغرض سو اء كان الحصول على مظهر أكثر طو لا و أقل أمتلاءا فستخدم الخطوط الطولية أو مظهر ممتلىء وأقل طو لا فنستخدم الخطوط العرضية ، أو مظهر ا أكثر ليونة وذلك من خلال إستخدام خطوط مائلة أو منحنية ...... ألخ فبشكل عام يمكننا تسخير الإمكانات الحركية المتتوعة لعنصر الخط فى تتنتيت الإنتباه عن مواضع العيوب الظاهرة فى جسم المر أة و التى تشكل مو اضع سلبية وجذب الانتباه للمو اضع الجميلة فى جسم المر اة وإبراز المناطق الإيجابية. - معالجة عيوب النمط النحيف تتطلب إستخدام خطوط الزى بشكل أكبر لعمل قصات وموديلات لها حجم وأرتفاع مؤثر كالدر ابيهات و الكر انبش و غبر ها من التفاصيل التى تزيد من الحجم العام و المساحة الكلية للجسم وبالتالى تعالج نحافة أماكن الجسم المختلفة أما فى النمط البدين فالتصميمات الطباعية ذات الأتجاهات الطولية و الألوان القاتمة و الموديلات البسيطة تكون أنسب الحلول المتاحة للوصول لمظهر عام أفضل . 
( (1) عبد العزيزجودة ، محمد حافظ الخولى ، ضحى مصطفي عبد المنعم : "اسساسيات تصميم الملابس" ، دار التوفيق النوذجية ،

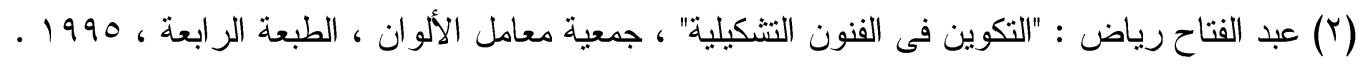

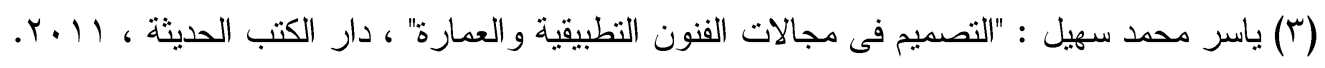

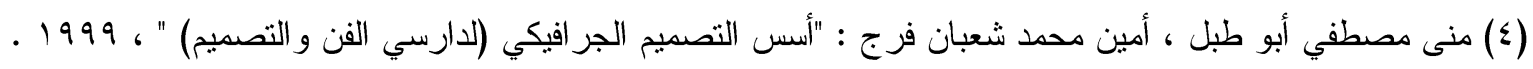

(5) Susan Meller and Joost Elffers : "Textile Designs", Harry N Abrams publishing Ltd, USA , 1991.

(ך) هناء فهمي حماد : " منطلبات بناء وحدة الثنكل الإسلامي المطبو ع للتصميم البنائي لزى المر أة " ، رسالة ماجستير ، كلية

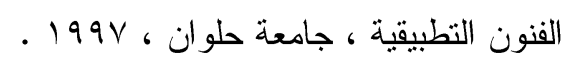

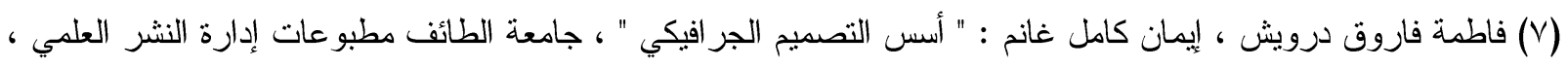
.$r .1 \varepsilon$

(^) هدى عبد الرحمن محمد الهادى ، محمد محمود محمد عفيفي : " أساسيات تصميم وطباعة المنسوجات ومشروعات

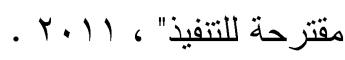

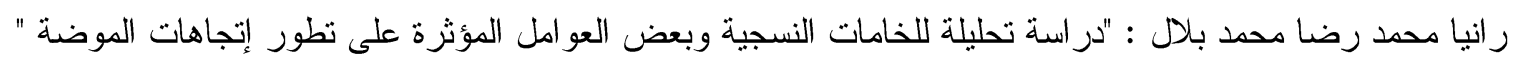

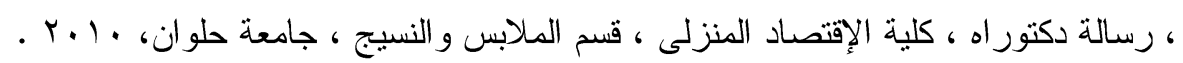

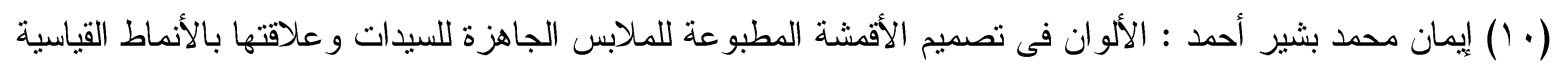

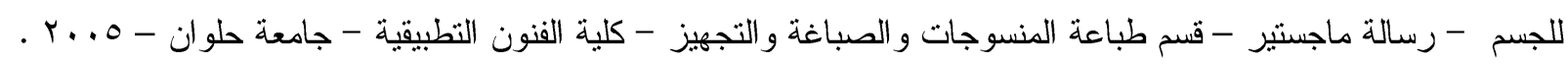

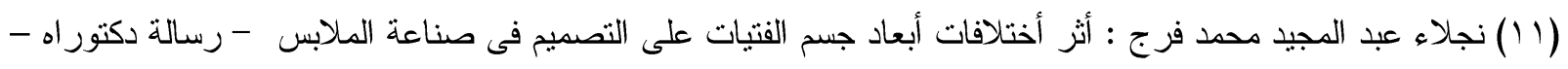

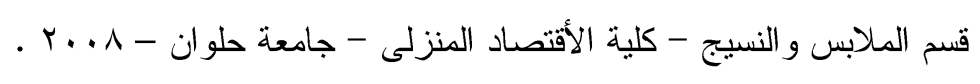

(12) Trinny \& Susannah: "The Body Shape Bible", Weidenfled \& Nicolson, 2002.

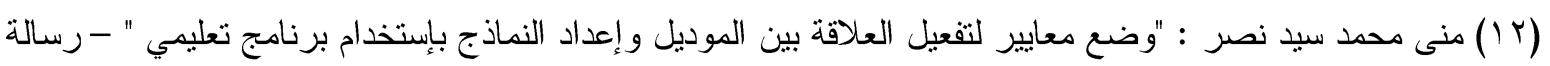

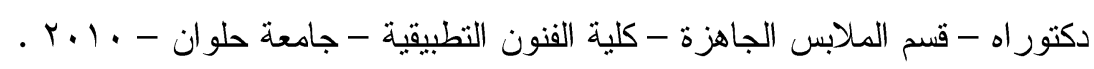

